\title{
Geoinformatics for Quantifying Salt Affected Soils in Gohana, Haryana Using Soil Techniques
}

\author{
Mohammad Amin Bhat*, M.S. Grewal, Dinesh, Inderpal Singh and K.S. Grewal \\ Department of Soil Science, CCS Haryana Agricultural University, \\ Hisar-125004, Haryana, India \\ *Corresponding author
}

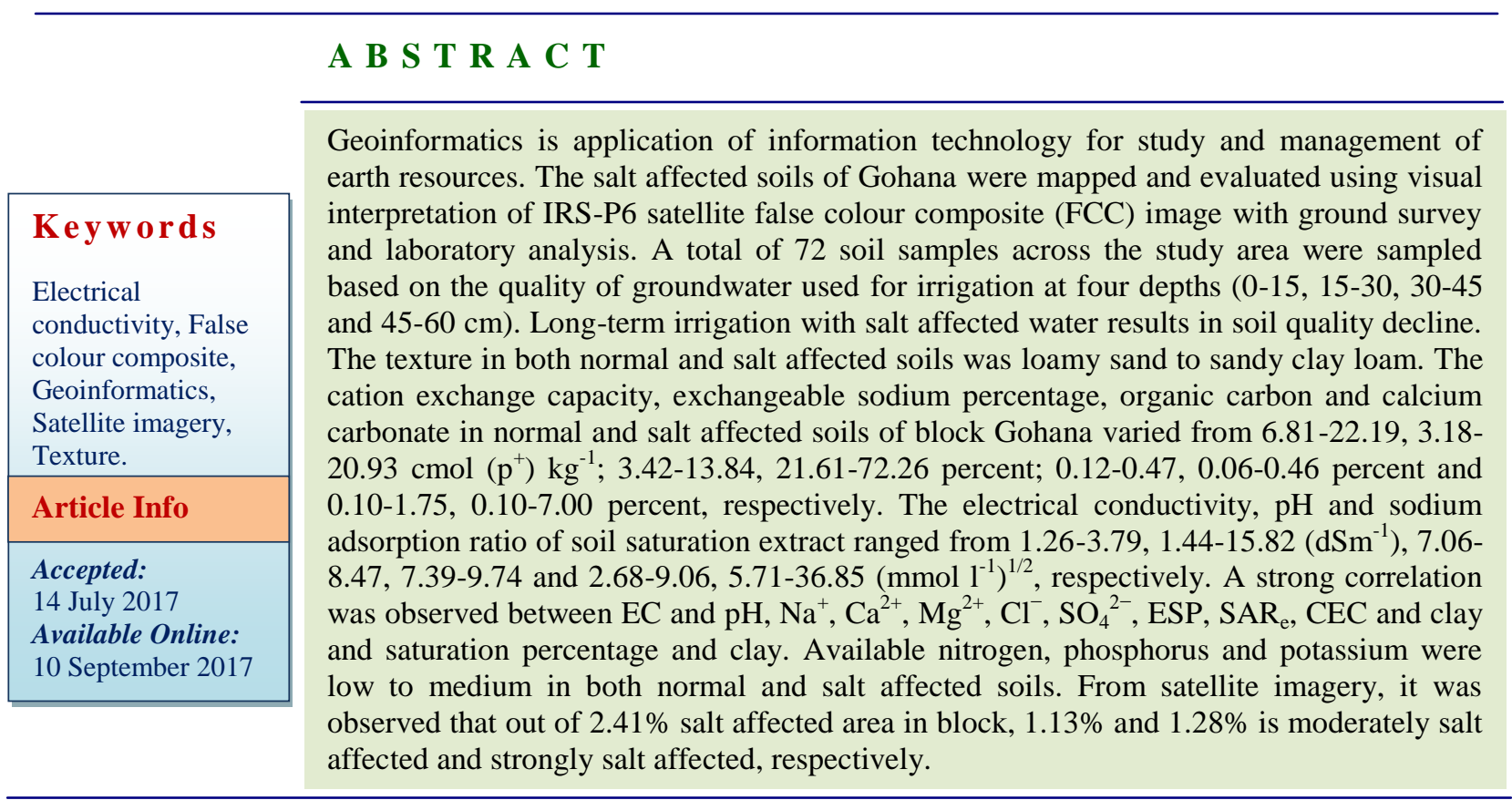

\section{Introduction}

In addition to water scarcity, water quality deterioration is anticipated to escalate in arid and semi-arid regions of India due to anthropogenic activities and extreme consequences of climate change. On longterm basis, irrigation with salt affected water results in soil quality decline. The increased accrual of soluble salts at or near surface horizons of soil poses a major threat with serious global economical and social consequences. This accumulation of soluble salts hastens land degradation processes thereby decrease crop yields and agricultural production (FAO, 1988; Farifteh et al., 2007). The irrigated agriculture is beset with the problem of soil salinity and in over 100 countries, $20 \%$ of the total irrigated lands and $10 \%$ of the total arable land have been struck by various kinds and levels of salinity (Ghassemi et al., 1995; Bilgili, 2013). In India, salt affected soils occupy $2 \%$ of the geographical area, mainly present in arid and semi-arid regions and coastal areas (Mandal and Sharma, 2010). 
Accumulation of salts in the soil as a result of salinization endangers the sustainability of agricultural and natural soils. So far as soil degradation is concerned, salinization and sodification are the principal processes influencing irrigated lands. The raising development of irrigated farming is indispensable for sustainable production of food needed by the burgeoning global population. However, there is enhancing paucity and low quality of available resources in addition to competitive usage of these resources for other functions thereby impeding the development of irrigated agriculture. Moreover, surface and groundwater resources are contaminated by the drainage effluents of irrigated lands (Ildefonso Pla Sentís, 2014).

With the development of technology, the application of new prospects of information technology and science to soil survey has come into existence (McBratney et al., 2003). Geoinformatics is application of information technology for study and management of earth resources (Bhat et al., 2015). The prime manifestation in soil resource evaluation via geographic information system is the creation of digital property and class maps with the constraint of relatively inadequate expansive fieldwork and subsequent laboratory analysis (McBratney et al., 2003). There has been an increasing need for soil information in recent years. Soil maps are used in many studies such as land evaluation, land suitability analysis, land use planning and GIS applications (Salehi et al., 2003).

Proactive supervising of salt build up is indispensable to limit its negative effects. Salinity monitoring requires the identification of areas where salts accumulate and the detection of temporal and spatial changes in their occurrence (Zinck, 2000; Muller and Niekerk, 2016). Remotely sensed data can play a great role in monitoring these processes on account of its capability to acquire information in both spatial and temporal scales (Abbas et al., 2013; Muller and Niekerk, 2016). Bastiaanssen et al., (2000) reported that remote sensing has the capability to envisage soil salinity, perform diagnosis and evaluate its impact. The combination of remote sensing with field surveys can save labour, time and effort in comparison to sole regular field surveys used for monitoring salt accumulation (Metternicht, 1996; Eldiery et al., 2005; Muller and Niekerk, 2016).

The state of Haryana (India) is one of the most agriculturally productive areas of the country and is of broad agro-ecological significance. Due to the lack of proper drainage in Gohana block, district Sonipat (Haryana), continued agricultural productivity is jeopardised, since limitations have been enforced on the discharge of drainage water to surface water supplies. By and large, the drainage water is disposed to groundwater beneath irrigated lands or to permanent evaporation ponds. Therefore, the study was undertaken by applying geoinformatics to quantify salt affected soils in Gohana using soil techniques.

\section{Materials and Methods}

\section{Study area}

The study area forms a part of the IndoGangetic plains and displays flat terrain with general slope from north to south. The area is devoid of any high topographic features. However, a natural depression exists in north and northwest of block. The maximum elevation of the plain is about $230 \mathrm{~m}$ above mean sea level. Gohana is situated at $28^{\circ} 57^{\prime}$ and $29^{\circ} 12^{\prime} \mathrm{N}$ latitude to $76^{\circ} 38^{\prime}$ and $76^{\circ} 52^{\prime} \mathrm{E}$ longitude. The climate of the area is subtropical, semi-arid with hot dry summer and cold winter. Around 80 percent of the 
total rainfall occurs during the southwest monsoon (July-September). July is the wettest month of year with 7.5 rainy days and 169 $\mathrm{mm}$ rainfall. January is the coldest month with maximum and minimum temperature of $21.3^{\circ} \mathrm{C}$ and $7.3^{\circ} \mathrm{C}$, respectively. Usually there is an increase in temperature in April and Rabi (winter) crops ripe a week earlier than Baisakhi. The temperature continues to rise until June, which is the hottest month (Central Groundwater Board, 2008).

\section{Soil sampling}

A total of 72 soil samples across the study area were sampled based on the quality of groundwater used for irrigation at four different depths ( 0 to 15,15 to 30,30 to 45 and 45 to $60 \mathrm{~cm}$ ) and subsequently air dried and sieved $(2 \mathrm{~mm})$ for laboratory analysis. Soil sampling was carried out before the showers of monsoon when the salt accumulation is generally highest. The geographical locations (UTM coordinates) of the sampling locations were recorded using handheld GPS.

\section{Laboratory analysis}

Soil EC and other soil salinity indicators were determined in soil water extractions obtained from saturation pastes that were prepared from $100 \mathrm{~g}$ air dried and 2-mm sieved soil. EC (in $\mathrm{dS} \mathrm{m}^{-1}$ ) and $\mathrm{pH}$ were measured using $\mathrm{EC}$ and $\mathrm{pH}$ meter, saturation percentage, soluble cations- $\mathrm{Ca}^{2+}, \mathrm{Mg}^{2+}, \mathrm{Na}^{+}$and $\mathrm{K}^{+}$and soluble anions- $\mathrm{CO}_{3}{ }^{2-}, \mathrm{HCO}_{3}{ }^{-}, \mathrm{Cl}^{-}$and $\mathrm{SO}_{4}{ }^{2-}$ - were determined using standard procedures underlined in USDA Handbook No. 60 (Richards, 1954). Particle size distribution of the soils was determined by International Pipette method (Piper, 1966). Organic carbon was determined by wetoxidation method (Walkely and Black, 1934), available nitrogen $(\mathrm{N})$ was determined by alkaline permanganate method (Subbaiah and Asija, 1956), available $P$ content was determined by extracting the soil samples using $0.5 \mathrm{M} \quad \mathrm{NaHCO}_{3}$ and analysed by spectrophotometer (Olsen et al., 1954) and available potassium was extracted by using neutral normal ammonium acetate and the content was determined by aspirating the extract into flame photometer (Jackson, 1973). Cation exchange capacity (CEC) and exchangeable sodium $\left(\mathrm{Na}_{\mathrm{Exc}}\right.$; meq $\left.100 \mathrm{~g}^{-1}\right)$ were determined by ammonium acetate method (Hesse, 1972). Exchangeable sodium percentage was calculated as follows:

$$
\mathrm{ESP}=\frac{\mathrm{Na}_{E x c}}{\mathrm{CEC}} \times 100
$$

\section{Methodology for map preparation}

The methodology essentially involves georeferencing of satellite data, delineation of salt affected categories through on screen visual interpretation technique based on legacy data and limited ground truth. Three seasons Resource Sat -1 LISS III satellite data viz. Kharif, Rabi, and Zaid for 2008-2009 were used for delineation of salt affected areas. The satellite data was geo-coded and rectified using ortho-rectified LandSat ETM+ images. The details of the satellite data used for the study are given in table 1 .

\section{Image interpretation}

Based on the standard image characteristics such as tone, texture, pattern, shape, size, location and association etc. on screen visual interpretation of remotely sensed data was carried out using a hybrid approach. Interpretation "keys" were developed for various salt affected categories. These interpretation "keys" formed the base for delineation of the satellite data. Based on these interpretation keys, satellite data was classified into various salt affected classes based on their occurrence in the block. Different salt affected categories were delineated by following a standard legend 
prepared by Department of Space. These maps were put in GIS format to create the database. The datum and projection system of the satellite data was taken as WGS 84 and UTM, respectively. Arc GIS Desktop 9.2 and ERDAS Imagine were used for generation of vector layer and geo-referencing, respectively.

\section{Ground verification}

Due to variability of salt affected classes and terrain characteristics in the study area, ground truth in the block was collected along with the ground photographs. The doubtful areas in the pre-field interpreted maps were checked during the ground truth and the prefield maps were modified by incorporating field observations, if any. After due corrections, attributes were attached. The maps were composed in Arc Map 9.2 software to display the different layers of the extracted information in an effective manner for this purpose, the different layers of extracted information in.shp format were loaded in Arc Map and the maps were composed having legend to represent the categories of different classes. The Arc Map was also used to create various thematic maps like EC, ESP and pH maps of the study area.

\section{Statistical analysis}

Descriptive statistical methods were used to analyse the range, mean, standard deviation, variance, coefficient of variation, kurtosis, and skewness of all properties described in laboratory analysis. The correlation analysis was done to determine the relationship among various parameters. These analyses were processed using software SPSS 19.0.

\section{Results and Discussion}

Soil is a continuum and its constituents are versatile. The summary of the descriptive statistics of soil properties is given in tables 3 and 4 . The coefficient of variation $(\mathrm{CV})$ is an indicator of the general variation or heterogeneity of a given variable. In this study, a soil property is regarded as showing little variation where the $\mathrm{CV}$ is $<20$, moderate variability if the $\mathrm{CV}$ is between $20-50$ and high variability where the $\mathrm{CV}$ is above 50 (Ameyan, 1986).

\section{Soil pH}

Statistical analysis indicated that mean $\mathrm{pH}$ of both normal and salt affected soils decreased with depth which may be attributed to the high concentration of exchangeable sodium in the surface layer that occurs due to capillary rise as conditioned by high evapotranspiration. Moreover, leaching of salts had not taken place from upper to lower layers as sampling was done prior to monsoon. Standard deviation, variance and coefficient of variation of normal soils increased with depth (Table 3). On the otherhand, in salt affected soils standard deviation, variance and coefficient of variation first decreased and then increased with depth with lowest value observed in 15$30 \mathrm{~cm}$ depth (Table 4). Arguably, $\mathrm{pH}$ is the single most diagnostic chemical measurement made on soil as it expresses the degree of acidity or alkalinity influencing a wide range of soil properties that is chemical, biological and indirectly even physical. The $\mathrm{pH}$ in normal and salt affected soils ranged from 7.06 to 8.42 and 7.39 to 9.74 , respectively (Table 3) indicating the neutral to alkaline nature of soil $\mathrm{pH}$. There is a positive and significant correlation between $\mathrm{pH}$ and $\mathrm{EC}(\mathrm{r}$ $=0.57 ; \mathrm{p} \leq 0.01) \mathrm{pH}$ and $\mathrm{Na}^{+}(\mathrm{r}=0.59 ; \mathrm{p} \leq 0.01)$ and $\mathrm{Cl}^{-}(\mathrm{r}=0.63)$ and $\mathrm{SO}_{4}{ }^{2-}(\mathrm{r}=0.51)$ signifying that the $\mathrm{pH}$ of the soil is primarily influenced by the $\mathrm{Cl}^{-}$and $\mathrm{SO}_{4}{ }^{2-}$ content (Table 2). Bai et al., (2016) also reported positive correlation between $\mathrm{pH}$ and $\mathrm{EC}$ and $\mathrm{Na}^{+}$ions in the Wuyu'er-Shuangyang River 
Basin, Northeast China. The $\mathrm{pH}$ variation in the area is small as indicated by low $\mathrm{CV}$ which can be attributed to high buffering capacity of the soils and absence of carbonates in the saturation extract (Sharma and Gupta, 1986). Higher $\mathrm{pH}$ values were recorded at various sites across the block which may be attributed to the existence of soluble and exchangeable sodium along with bicarbonate ions which get precipitated as calcium and magnesium carbonates during evaporation (Deshmukh, 2012). Tripathi et al., (2015) also reported low CV for $\mathrm{pH}$ while characterizing the spatial variability of soil properties in salt affected area. The high $\mathrm{pH}$ in the soils suggests that groundwater was the main source of contamination in the study area. Hence, high $\mathrm{pH}$ values are the indication of development of salinity and sodicity in the study area. Similar results were confirmed by Sidhu et al., (1991).

\section{Electrical conductivity $\left(\mathrm{EC}_{\mathrm{e}}\right)$ of saturation extract}

Statistical analysis of electrical conductivity indicated that its mean decreased consistently but standard deviation and variance showed irregular trend down with depth in normal soils (Table 3). However, in salt affected soils, mean, standard deviation and variance decreased constantly with depth (Table 4). This indicates the upward movement of soluble salts in the soil profile and their ultimate deposition in the surface layers which may ultimately result in the development of salt affected soils in the long run. The EC showed medium and medium to high variability in normal and salt affected soils with CV values from 29.01 to 37.10 and 46.06 to $59.46 \%$, respectively (Tables 3 and 4). In salt affected soils, the highest $\mathrm{CV}$ was in $0-15 \mathrm{~cm}$ depth and lowest in $45-60 \mathrm{~cm}$ depth. Such trend may be due to more severe wetting and drying cycles in which soluble salts present in the dry beds are transported to the surface soil by upward capillary movement. Corwin and Lesch (2005) reported moderate to high variability in $\mathrm{EC}_{\mathrm{e}}$ in salinesodic soil. Zhaoyong et al., (2014) observed moderate variability in $\mathrm{EC}_{\mathrm{e}}$ while assessing the soil salinization risk in Yanqi basin, northwest China. Electrical conductivity is an important diagnostic parameter for evaluation of soil salinity. The EC varied from 1.26 to 3.79 and 1.44 to 15.82 in normal and salt affected soils, respectively. The $\mathrm{EC}_{\mathrm{e}}$ showed a decreasing trend with depth which may be due to the capillary rise of brackish groundwater to the soil surface followed by evaporation leaving behind salts. Since, potential evapotranspiration is higher than precipitation as the mercury touches about $45^{\circ} \mathrm{C}$ during summers. Other probable explanation is the evaporation of rainwater that accumulates in comparatively lower topographic positions on which the salt affected soils are situated (Sidhu et al., 1991). Qureshi et al., (1996) and Mandal (2014) reported that the higher $\mathrm{EC}_{\mathrm{e}}$ at surface may be due to the salt accumulation through run off. There was a significant correlation of 0.96 $(\mathrm{p} \leq 0.01)$ between $\mathrm{EC}_{\mathrm{e}}$ and $\mathrm{Na}^{+}$ions as well as and $\mathrm{Cl}^{-}(\mathrm{r}=0.96)$ and $\mathrm{SO}_{4}{ }^{2-}(\mathrm{r}=0.74)$, ESP $(\mathrm{r}$ $=0.68)$, SAR $_{\mathrm{e}}(\mathrm{r}=0.79), \mathrm{pH}(\mathrm{r}=0.59)$. Moreover, a significant correlation of 0.63 $(\mathrm{p} \leq 0.05)$ between $\mathrm{EC}_{\mathrm{e}}$ and $\mathrm{Ca}^{2+}$ and $\mathrm{Mg}^{2+}$ $(0.46 ; p \leq 0.05)$ was observed. Das and Singh (2006) also reported strong linear relationship between $\mathrm{EC}_{\mathrm{e}}$ and $\mathrm{Na}^{+}, \mathrm{Ca}^{2+}, \mathrm{Mg}^{2+}, \mathrm{Cl}^{-}$and $\mathrm{SO}_{4}{ }^{2-}$ ions and evinced that the contribution of $\mathrm{Na}^{+}$and $\mathrm{Cl}^{-}$was more pronounced than other cations and anions. However, there is a negative significant correlation between $\mathrm{EC}_{\mathrm{e}}$ and organic carbon. The correlation coefficient between $\mathrm{EC}$ and $\mathrm{Na}^{+}$was higher than that between $\mathrm{pH}$ and $\mathrm{Na}^{+}$which implies that other non-alkaline salts also contribute to electrical conductivity.

\section{Cation exchange capacity (CEC)}

The mean values of CEC decreased consistently with depth in both normal and 
salt affected soils. However, standard deviation and variance showed irregular trend with depth in both normal and salt affected soils (Tables 3 and 4). The CEC at all soil depths showed a medium range of variability as indicated by coefficient of variation (CV) values. The $C V$ value was slightly higher for surface soil $(0-15 \mathrm{~cm})$ in salt affected soils and for sub soil in normal soils $(45-60 \mathrm{~cm})$. Hence, the variation differed appreciably among four soil depths studied. The medium $\mathrm{CV}$ for CEC was due to medium variation in silt and clay fractions of soil texture (Table 2). Ameyan (1986) has reported relatively high range of variation in CEC with $\mathrm{CV}$ values of $>$ 30. Corwin and Lesch (2005) also reported moderate variability in CEC in saline-sodic soil. The cation exchange capacity ranged from 6.81 to 22.19 and 3.18 to $20.93 \mathrm{cmol}$ $\left(\mathrm{p}^{+}\right) \mathrm{kg}^{-1}$ in normal and sodic soils, respectively. Cation exchange capacity decreased with depth which may be attributed to higher concentration of exchangeable cations in upper layers. Moreover, the sites having higher cation exchange capacity have high clay content and relatively higher organic matter which are responsible for adsorption of exchangeable cations. There is a positive and significant correlation between CEC and $\mathrm{OC}(\mathrm{r}=0.31 ; \mathrm{p} \leq 0.05)$ and clay $(\mathrm{r}=$ $0.44 ; \mathrm{p} \leq 0.05)$ suggesting that organic matter and clay content determine the cation exchange capacity. However, the higher contribution was shown by clay content. The lower CEC values may be related to coarse soil texture (Mandal, 2014); dominance of illite mineral, other low charge minerals and low organic matter content (Sharma et al., 2011, Dinesh et al., 2017). On the otherhand, negative and significant relationship between CEC and sand content $(r=-0.35 ; p \leq 0.05)$ was observed which may be due to dominance of quartz mineral. Wang et al., (2005) also reported negative correlation between soil $\mathrm{CEC}$ and sand content $(\mathrm{r}=-0.43)$ in the calcareous soils with a wide range of $\mathrm{CaCO}_{3}$.

\section{Sodium adsorption ratio (SAR)}

Statistical analysis showed that mean, standard deviation and variance of sodium adsorption ratio in both normal and salt affected soils decreased with depth, the highest being observed in the surface layer ( 0 $15 \mathrm{~cm})$. The CV in normal soils was medium to high whereas in salt affected soils CV was high (Tables 3 and 4). Corwin and Lesch (2005) also reported moderate to high variability in SAR in saline-sodic soil. However, Yang et al., (2011) reported high range of variation in SAR with CV values of 119-197\%. Zhaoyong et al., (2014) observed high variability in SAR while assessing the soil salinization risk in Yanqi basin, northwest China. The sodium adsorption ratio of the saturated extract of normal and salt affected soils varied from 2.68 to 9.06 and 5.71 to $36.85\left(\mathrm{mmol} \mathrm{l}^{-1}\right)^{1 / 2}$, respectively. Positive and significant relationship $(\mathrm{p} \leq 0.01)$ was observed between SAR and $\mathrm{Na}^{+}(\mathrm{r}=0.90), \mathrm{Cl}^{-}(\mathrm{r}=0.72)$ and $\mathrm{SO}_{4}{ }^{2-}(\mathrm{r}=0.66)$. Significant and positive correlation was observed between ESP and SAR suggesting that higher SAR is accompanied by high ESP. Mohamed et al., (2008) also reported positive and significant relationship between ESP and SAR in Vertisols of Sudan.

\section{Exchangeable sodium percentage (ESP)}

Exchangeable sodium percentage determines the percentage of exchangeable sodium adsorbed on soil exchange complex and is used to test soil sodicity. Statistical analysis showed that the mean, standard deviation and variance of exchangeable sodium percentage decreased with depth in both normal and salt affected soils and highest ESP was observed in the surface layer $(0-15 \mathrm{~cm})$. Exchangeable sodium percentage showed medium variation as reflected by the coefficient of variation (Tables 3 and 4). The exchangeable sodium percentage in normal and salt affected soils 
varied from 3.42 to 13.84 and 21.61 to 72.26 percent, respectively. The lower ESP in normal soils could be assigned to the effect of $\mathrm{Ca}$ and $\mathrm{Mg}$ to offset the effect of $\mathrm{Na}$ on cation exchange complex of the soil colloids. Contrarily, the higher ESP in sodic and saline-sodic soils might be due to higher carbonates, bicarbonates and hydroxide ion concentrations in these soils that may engender the calcium to precipitate as $\mathrm{CaCO}_{3}$. There was a significant correlation of 0.73 $(\mathrm{p} \leq 0.01)$ between ESP and $\mathrm{Na}^{+}$ions and $\mathrm{pH}(\mathrm{r}$ $=0.79$ ) which implies that higher $\mathrm{pH}$ is responsible for high ESP as $\mathrm{Na}^{+}$was the dominant ion in the saturation extract.

Significant negative correlation was observed between ESP and OC $(r=-0.31 ; p \leq 0.01)$ suggesting that organic matter has buffer effect for sodic soils. The decrease in ESP with depth indicates that process of alkalization had started at the surface and proceeded in downward direction. Mitran et al., (2015) reported ESP values of 0.11 to $66 \%$ suggesting the impact of sodium hazard in soil which were mostly saline-sodic in nature (40\%) while Eldardiry et al., (2013) reported ESP values of 12.78 to $67.27 \%$ in saline sodic soils of Egypt.

\section{Major cations and anions}

The ionic composition in both normal and salt affected soils showed more or less high variation as revealed by $\mathrm{CV}$ values (Tables 3 and 4). The cations $\mathrm{Ca}^{2+}, \mathrm{Mg}^{2+}, \mathrm{Na}^{+}$and $\mathrm{K}^{+}$ varied from 3.36-11.78, 2.40-9.84, 5.88$29.64,0.38-2.45$ and 1.64-19.34, 1.42-15.28, 7.04-134.92, 0.18-4.13 meq $\mathrm{l}^{-1}$ in normal and salt affected soils, respectively. The anions $\mathrm{CO}_{3}{ }^{2-}, \mathrm{HCO}_{3}{ }^{-}, \mathrm{Cl}^{-}$, and $\mathrm{SO}_{4}{ }^{2-}$ ranged from traces to $3.08,2.46-18.10,5.50-25.32,0.79$ 15.91 and traces to $4.80,2.32-23.96,6.64-$ $88.93,0.24-69.12 \mathrm{meq}^{-1}$ in normal and salt affected soils, respectively. Both cations and anions showed a decreasing trend with depth which may be due to the upward movement of the ions with the capillary water during the summer months as the rise in temperature leads to high evapotranspiration thereby increasing the concentration of these ions in surface layers. Moreover, the sampling was done before the showers of monsoon. Salinity in these soils was the result of chloride and sulphate salts of $\mathrm{Na}^{+}$existing in large amount (as the concentration of $\mathrm{CO}_{3}{ }^{2-}$ and $\mathrm{HCO}_{3}{ }^{-}$ was low) and are the salts of strong acids and bases, therefore, completely dissociate in water (Das and Singh, 2006). Scott and Smith (1987) reported that under irrigated conditions in arid regions the alkali cations may concentrate at the soil surface due to upward capillarity and evaporation. A positive and significant correlation was observed between $\mathrm{Na}^{+}$ions and $\mathrm{Cl}^{-}(\mathrm{r}=0.923 ; \mathrm{p} \leq 0.01)$ and $\mathrm{SO}_{4}{ }^{2-}$ $(\mathrm{r}=0.818 ; \mathrm{p} \leq 0.01)$ indicating that chloride was the primary salt anion and sulphate was the secondary. Calcium $\left(\mathrm{Ca}^{2+}\right)$ showed positive relationship with $\mathrm{Cl}^{-}(\mathrm{r}=0.494$; $\mathrm{p} \leq 0.01)$. The cations in the saturation extract were significantly correlated with each other except $\mathrm{K}^{+}$, however, $\mathrm{K}^{+}$showed significant correlation with $\mathrm{Mg}^{2+}$ (Table 2). In this study, the bicarbonates were observed in all samples but carbonates were only detected in samples having high $\mathrm{pH}$ values. This is due to precipitation of calcium and magnesium as carbonates.

\section{Calcium carbonate $\left(\mathrm{CaCO}_{3}\right)$}

In normal and salt affected soils calcium carbonate ranged from 0.10 to 1.75 and 0.10 to 7.00 percent, respectively (Tables 3 and 4). The calcium carbonate showed highest variation as defined by the coefficient of variation both in normal and salt affected soils, albeit, $\mathrm{CaCO}_{3}$ is a basic property but it is a local phenomenon which may be accountable to its high variability. Moreover, the variation may be ascribed to the nature of parent material and quality of irrigation water used. Saldana et al., (1998) reported high 
variation in $\mathrm{CaCO}_{3}$ with $\mathrm{CV}$ values upto $550 \%$ while studying spatial variability of soil properties in chronosequence on terraces of Henares River. Negative but significant correlation was observed between $\mathrm{CaCO}_{3}$ and $\mathrm{P}(\mathrm{r}=-0.29 ; \mathrm{p} \leq 0.05)$ which may be assigned to fixation of $\mathrm{P}$ as calcium phosphate; $\mathrm{CaCO}_{3}$ and $\mathrm{pH}(\mathrm{r}=-0.24 ; \mathrm{p} \leq 0.05)$ because at higher $\mathrm{pH}$, i.e., at 8.3 saturation of calcium carbonate occurs; $\mathrm{CaCO}_{3}$ and $\mathrm{K}(\mathrm{r}=-0.38 ; \mathrm{p} \leq 0.01)$, $\mathrm{Mg}^{2+}(\mathrm{r}=-0.29 ; \mathrm{p} \leq 0.05)$ and $\mathrm{Cl}^{-}(\mathrm{r}=-0.25$; $\mathrm{p} \leq 0.05)$ which may be attributed to the shielding action of water as done by these ions which will make it difficult for $\mathrm{Ca}^{2+}$ and $\mathrm{CO}_{3}{ }^{2-}$ ions to find each other and precipitate, moreover, the effect would be greater for divalent ions than univalent ions since the attraction for multiple charged ions should be greater (Krauskopf, 1967). Calcium carbonate showed increasing trend with depth which may be ascribed to poor drainage conditions. Babar and Kaplay (2004) reported that the $\mathrm{CaCO}_{3}$ was higher in salt affected soils as compared to normal soils but increased with depth.

\section{Organic carbon (OC)}

The organic carbon varied from 0.12 to 0.47 and 0.06 to 0.46 percent in normal and salt affected soils, respectively (Tables 3 and 4). Organic carbon content decreased consistently with depth. This trend in organic carbon content is expected because in nearly all soils organic carbon in the surface layer is always higher due to addition through farmyard manure and plant residues. The statistical analysis showed a considerable lower range of variability of OC. Soil organic carbon was higher in normal soils compared to salt affected soils which may be ascribed to higher decomposition of organic matter in salt affected soils (sodic) due to dispersion of soil aggregates. The low CV in OC content in the surface layer may be attributed to the rapid oxidation of organic matter and levelling effect of cultivation. Higher $\mathrm{CV}$ at lower depths may be caused by root residues left in the sub soil. In terms of magnitude of variation, the variation in $\mathrm{OC}$ in the study area was low to medium. Bhatti (2002) observed medium range of variability in organic matter with CV value of $34.66 \%$. Corwin and Lesch (2005) reported moderate variability in total carbon in saline-sodic soil. The OC in the study area was low and showed a decreasing trend with depth which might be ascribed to the prevailing high temperature that is responsible for rapid mineralization of organic matter, as it is not unexpected in subtropical and tropical climates.

\section{Available nitrogen}

Statistical analysis of available nitrogen showed that the mean, variance and standard deviation of this parameter decreased more or less with depth in normal soils. However, in salt affected soils these parameters increased with depth except mean (Tables 3 and 4). The mean value of available nitrogen in all locations was low.

Table.1 Details of satellite data

\begin{tabular}{|c|c|c|c|}
\hline Satellite & Sensor & Date of Acquisition & Spatial Resolution \\
\hline IRS-P6 & LISS-III & May, 2009 & 23.5 metres \\
\hline & & 11 March, 2009 & \\
\hline & & 13 October, 2008 & \\
\hline
\end{tabular}




\section{Int.J.Curr.Microbiol.App.Sci (2017) 6(9): 835-858}

Table.2 Correlation coefficient among various parameters of soil

\begin{tabular}{|c|c|c|c|c|c|c|c|c|c|c|c|c|c|c|c|c|c|c|c|c|c|c|}
\hline & $\mathrm{OC}$ & $\mathrm{CaCO}_{3}$ & $\mathrm{~N}$ & $\mathrm{P}$ & $\mathrm{K}$ & ESP & $\mathrm{EC}_{\mathrm{e}}$ & $\mathrm{pH}$ & $\mathrm{Ca}^{2+}$ & $\mathrm{Mg}^{2+}$ & $\mathrm{Na}^{+}$ & $\mathrm{K}^{+}$ & $\mathrm{CO}_{3}{ }^{2-}$ & $\mathrm{HCO}_{3}$ & $\mathrm{Cl}^{-}$ & $\mathrm{SO}_{4}{ }^{2-}$ & $\mathrm{SAR}_{\mathrm{e}}$ & SP & Sand & Silt & Clay & CEC \\
\hline $\mathrm{OC}$ & 1 & & & & & & & & & & & & & & & & & & & & & \\
\hline $\mathrm{CaCO}_{3}$ & -0.17 & 1 & & & & & & & & & & & & & & & & & & & & \\
\hline $\mathrm{N}$ & $0.31^{* *}$ & $-0.37^{* *}$ & 1 & & & & & & & & & & & & & & & & & & & \\
\hline $\mathrm{P}$ & $0.66^{* *}$ & $-0.28^{*}$ & $0.35^{* *}$ & 1 & & & & & & & & & & & & & & & & & & \\
\hline $\mathrm{K}$ & $0.64^{* *}$ & $-0.38^{* *}$ & $0.33^{* *}$ & $0.49^{* *}$ & 1 & & & & & & & & & & & & & & & & & \\
\hline ESP & $-0.35^{* * *}$ & -0.18 & 0.14 & 0.05 & -0.15 & 1 & & & & & & & & & & & & & & & & \\
\hline $\mathrm{EC}_{\mathrm{e}}$ & 0.05 & -0.13 & $0.25^{*}$ & 0.09 & 0.22 & $0.67^{* *}$ & 1 & & & & & & & & & & & & & & & \\
\hline $\mathrm{pH}$ & -0.19 & $-0.24^{*}$ & 0.07 & 0.04 & -0.07 & $0.86^{* *}$ & $0.57^{* *}$ & 1 & & & & & & & & & & & & & & \\
\hline $\mathrm{Ca}^{2+}$ & $0.35^{* *}$ & -0.05 & 0.19 & $0.31^{* *}$ & $0.36^{\text {** }}$ & 0.22 & $0.63^{\text {*** }}$ & $0.25^{*}$ & 1 & & & & & & & & & & & & & \\
\hline $\mathrm{Mg}^{2+}$ & $0.25^{*}$ & $-0.29^{*}$ & $0.29^{*}$ & $0.28^{*}$ & $0.44^{* *}$ & 0.19 & $0.46^{\text {*** }}$ & $0.33^{* *}$ & $0.78^{* *}$ & 1 & & & & & & & & & & & & \\
\hline $\mathrm{Na}^{+}$ & -0.01 & -0.10 & $0.24^{*}$ & 0.03 & 0.15 & $0.72^{*:}$ & $0.96^{\text {*** }}$ & $.057^{* *}$ & $0.44^{* *}$ & $0.24^{*}$ & 1 & & & & & & & & & & & \\
\hline $\mathrm{K}^{+}$ & $0.33^{* *}$ & -0.01 & -0.18 & $0.29^{*}$ & $0.23^{*}$ & -0.09 & 0.13 & -0.03 & 0.21 & $0.23^{*}$ & 0.00 & 1 & & & & & & & & & & \\
\hline $\mathrm{CO}_{3}{ }^{2-}$ & $0.37^{* *}$ & 0.04 & 0.00 & 0.21 & 0.11 & -0.10 & 0.15 & -0.01 & 0.03 & 0.03 & 0.11 & $0.56^{* *}$ & 1 & & & & & & & & & \\
\hline $\mathrm{HCO}_{3}$ & $0.24^{*}$ & -0.01 & 0.04 & 0.08 & $0.23^{*}$ & -0.04 & 0.22 & 0.04 & 0.09 & $0.37^{* * *}$ & 0.14 & $0.48^{* *}$ & $0.69^{* *}$ & 1 & & & & & & & & \\
\hline $\mathrm{Cl}^{-}$ & 0.01 & $-0.25^{*}$ & $0.32^{* *}$ & 0.12 & $0.27^{*}$ & $0.72^{* *}$ & $0.94^{* * *}$ & $0.61^{\text {** }}$ & $0.63^{* *}$ & $0.47^{* *}$ & $0.91^{* * *}$ & 0.03 & -0.02 & 0.04 & 1 & & & & & & & \\
\hline $\mathrm{SO}_{4}{ }^{2-}$ & 0.00 & 0.07 & 0.13 & 0.05 & 0.03 & $0.54^{* * *}$ & $0.78^{* * *}$ & $0.38^{* *}$ & $0.46^{* *}$ & 0.10 & $0.82^{* * *}$ & -0.14 & -0.09 & $-0.24^{*}$ & $0.72^{* * 1}$ & 1 & & & & & & \\
\hline SARe & -0.13 & -0.04 & 0.19 & -0.06 & -0.03 & $0.74^{* * *}$ & $0.79^{* * *}$ & $0.58^{* *}$ & 0.08 & -0.05 & $0.90^{* *}$ & -0.06 & 0.17 & 0.19 & $0.72^{* * x}$ & $0.66^{* *}$ & 1 & & & & & \\
\hline $\mathrm{SP}$ & -0.11 & -0.07 & $-0.26^{*}$ & $0.23^{*}$ & 0.07 & 0.05 & -0.20 & 0.09 & -0.03 & 0.01 & -0.21 & -0.12 & $-0.37^{* *}$ & $-0.34^{* *}$ & -0.10 & -0.05 & $-0.24^{*}$ & 1 & & & & \\
\hline Sand & 0.00 & 0.11 & 0.18 & -0.12 & -0.01 & 0.09 & 0.18 & -0.06 & -0.01 & -0.06 & 0.21 & 0.21 & $0.28^{*}$ & 0.20 & 0.13 & 0.08 & $0.24^{*}$ & $-0.79^{\text {*** }}$ & 1 & & & \\
\hline Silt & 0.18 & -0.14 & -0.11 & 0.16 & 0.11 & -0.20 & -0.10 & -0.10 & -0.03 & 0.01 & -0.11 & -0.15 & -0.08 & 0.07 & -0.10 & -0.13 & -0.10 & $0.45^{* *}$ & $-0.81^{* *}$ & 1 & & \\
\hline Clay & -0.19 & -0.04 & -0.18 & 0.03 & $0.21^{*}$ & 0.04 & -0.19 & 0.11 & 0.05 & 0.08 & $-0.23^{*}$ & -0.19 & $-0.45^{* * *}$ & $-0.41^{* * *}$ & -0.11 & -0.03 & $-0.29^{*}$ & $0.84^{* *}$ & $-0.81^{* * *}$ & $0.32^{* *}$ & 1 & \\
\hline $\mathrm{CEC}$ & $0.31^{* *}$ & 0.14 & -0.04 & 0.17 & $0.32^{* *}$ & -0.13 & 0.20 & -0.02 & $0.66^{* *}$ & $0.45^{* *}$ & 0.06 & 0.11 & -0.04 & -0.10 & 0.21 & 0.22 & -0.20 & $0.38^{* *}$ & $-0.35^{* *}$ & 0.14 & $0.43^{* *}$ & 1 \\
\hline
\end{tabular}


Table.3 Descriptive statistics of soil characteristics (0-60 cm depth) of normal soils

\begin{tabular}{|c|c|c|c|c|c|c|c|c|}
\hline Characteristics & Minimum & Maximum & Mean & Std. Deviation & Variance & Skewness & Kurtosis & $\mathrm{CV}$ \\
\hline \multicolumn{9}{|c|}{$0-15 \mathrm{~cm}$ depth } \\
\hline SP & 31.52 & 41.02 & 35.14 & 3.19 & 10.19 & 1.05 & 1.00 & 9.08 \\
\hline Sand & 60.22 & 77.80 & 70.55 & 7.81 & 60.96 & -0.46 & -2.08 & 11.07 \\
\hline Silt & 9.65 & 20.60 & 14.40 & 4.54 & 20.63 & 0.43 & -2.21 & 31.53 \\
\hline Clay & 10.90 & 20.65 & 15.05 & 3.66 & 13.39 & 0.30 & -1.11 & 24.31 \\
\hline Silt+Clay & 22.20 & 39.78 & 29.45 & 7.81 & 60.96 & 0.46 & -2.08 & 26.51 \\
\hline CEC & 8.12 & 22.19 & 15.97 & 4.32 & 18.65 & -0.69 & 1.76 & 27.05 \\
\hline $\mathrm{OC}$ & 0.41 & 0.57 & 0.49 & 0.06 & 0.00 & 0.04 & -1.01 & 11.66 \\
\hline $\mathrm{CaCO}_{3}$ & 0.10 & 1.12 & 0.34 & 0.37 & 0.14 & 1.80 & 1.80 & 108.78 \\
\hline Available N & 104.37 & 220.40 & 156.17 & 36.17 & 1308.00 & 0.59 & 1.28 & 23.16 \\
\hline Available $\mathrm{P}$ & 16.52 & 28.77 & 20.35 & 4.36 & 19.04 & 1.37 & 1.66 & 21.44 \\
\hline Available K & 245.17 & 323.32 & 274.59 & 26.20 & 686.28 & 1.12 & 1.24 & 9.54 \\
\hline ESP & 3.96 & 13.84 & 9.66 & 3.85 & 14.85 & -0.16 & -1.62 & 39.89 \\
\hline $\mathrm{ECe}$ & 1.83 & 3.79 & 2.84 & 0.90 & 0.81 & 0.03 & -0.89 & 29.01 \\
\hline $\mathrm{pH}$ & 7.39 & 8.47 & 7.82 & 0.39 & 0.15 & 1.55 & 3.32 & 4.93 \\
\hline SARe & 3.11 & 9.06 & 5.85 & 3.00 & 9.01 & 1.21 & -0.06 & 51.35 \\
\hline \multicolumn{9}{|c|}{ Soluble cations in saturation extract $\left(\mathrm{meq}^{-1}\right)$} \\
\hline $\mathrm{Ca}^{2+}$ & 5.62 & 11.78 & 8.55 & 2.39 & 5.71 & 0.05 & -1.82 & 27.96 \\
\hline $\mathrm{Mg}^{2+}$ & 3.52 & 9.84 & 5.54 & 2.36 & 5.58 & 1.22 & 0.56 & 42.60 \\
\hline $\mathrm{Na}^{+}$ & 7.02 & 29.64 & 15.25 & 7.76 & 60.26 & 1.27 & 1.02 & 50.90 \\
\hline $\mathrm{K}^{+}$ & 0.69 & 2.45 & 1.47 & 0.58 & 0.34 & 0.59 & 0.13 & 39.58 \\
\hline \multicolumn{9}{|c|}{ Soluble anions in saturation extract $\left(\mathrm{meq}^{-1}\right)$} \\
\hline $\mathrm{CO}_{3}{ }^{2-}$ & 0.00 & 3.08 & 1.83 & 1.33 & 1.76 & -0.78 & -1.27 & 72.57 \\
\hline $\mathrm{HCO}_{3}^{-}$ & 4.20 & 18.10 & 9.68 & 4.88 & 23.83 & 0.78 & -0.18 & 50.41 \\
\hline $\mathrm{Cl}^{-}$ & 7.96 & 25.32 & 14.80 & 5.62 & 31.57 & 1.04 & 1.49 & 37.96 \\
\hline $\mathrm{SO}_{4}{ }^{2-}$ & 1.21 & 15.91 & 5.72 & 4.86 & 23.58 & 1.88 & 4.13 & 84.93 \\
\hline \multicolumn{9}{|c|}{$15-30 \mathrm{~cm}$ depth } \\
\hline SP & 30.86 & 40.36 & 34.18 & 3.09 & 9.54 & 1.48 & 2.86 & 9.03 \\
\hline Sand & 61.78 & 78.90 & 72.20 & 7.52 & 56.53 & -0.70 & -1.69 & 10.41 \\
\hline Silt & 9.70 & 19.40 & 13.62 & 3.98 & 15.85 & 0.70 & -1.57 & 29.24 \\
\hline Clay & 10.10 & 19.78 & 14.18 & 3.78 & 14.29 & 0.43 & -1.46 & 26.66 \\
\hline Silt+Clay & 21.10 & 38.22 & 27.80 & 7.52 & 56.53 & 0.70 & -1.69 & 27.05 \\
\hline CEC & 7.63 & 20.52 & 14.85 & 4.05 & 16.40 & -0.69 & 1.24 & 27.27 \\
\hline $\mathrm{OC}$ & 0.34 & 0.47 & 0.40 & 0.06 & 0.00 & 0.23 & -2.47 & 14.94 \\
\hline $\mathrm{CaCO}_{3}$ & 0.14 & 1.18 & 0.43 & 0.37 & 0.13 & 1.67 & 1.43 & 84.17 \\
\hline Available N & 98.22 & 211.60 & 141.81 & 34.81 & 1211.00 & 1.41 & 3.31 & 24.54 \\
\hline Available P & 10.20 & 22.69 & 15.27 & 4.19 & 17.60 & 0.86 & 0.46 & 27.46 \\
\hline Available K & 210.33 & 284.44 & 248.06 & 24.66 & 608.05 & -0.35 & -0.01 & 9.94 \\
\hline ESP & 3.85 & 12.81 & 9.31 & 3.52 & 12.38 & -0.30 & -1.31 & 37.80 \\
\hline $\mathrm{ECe}$ & 1.55 & 3.25 & 2.29 & 0.93 & 0.87 & 0.02 & -0.72 & 32.23 \\
\hline $\mathrm{pH}$ & 7.27 & 8.45 & 7.65 & 0.42 & 0.18 & 1.81 & 3.74 & 5.55 \\
\hline SARe & 3.00 & 8.77 & 5.55 & 2.65 & 7.02 & 1.08 & -0.70 & 47.73 \\
\hline \multicolumn{9}{|c|}{ Soluble cations in saturation extract $\left(\mathrm{meq}^{-1}\right)$} \\
\hline $\mathrm{Ca}^{2+}$ & 4.30 & 10.76 & 7.90 & 2.44 & 5.97 & -0.32 & -1.53 & 30.93 \\
\hline $\mathrm{Mg}^{2+}$ & 2.68 & 9.66 & 4.98 & 2.42 & 5.87 & 1.50 & 1.74 & 48.67 \\
\hline $\mathrm{Na}^{+}$ & 6.35 & 26.09 & 13.89 & 6.78 & 45.96 & 1.11 & 0.60 & 48.81 \\
\hline $\mathrm{K}^{+}$ & 0.53 & 2.36 & 1.30 & 0.61 & 0.37 & 0.91 & 0.45 & 46.87 \\
\hline
\end{tabular}


Int.J.Curr.Microbiol.App.Sci (2017) 6(9): 835-858

\begin{tabular}{|c|c|c|c|c|c|c|c|c|}
\hline $\mathrm{CO}_{3}{ }^{2-}$ & 0.00 & 2.82 & 1.61 & 1.18 & 1.40 & -0.70 & -1.37 & 73.68 \\
\hline $\mathrm{HCO}_{3}^{-}$ & 3.82 & 15.12 & 8.79 & 4.37 & 19.06 & 0.38 & -1.82 & 49.65 \\
\hline $\mathrm{Cl}^{-}$ & 6.84 & 24.04 & 13.43 & 5.65 & 31.96 & 1.11 & 1.38 & 42.09 \\
\hline $\mathrm{SO}_{4}{ }^{2-}$ & 1.12 & 15.42 & 5.22 & 4.83 & 23.35 & 1.96 & 4.25 & 92.61 \\
\hline \multicolumn{9}{|c|}{$30-45 \mathrm{~cm}$ depth } \\
\hline SP & 30.20 & 42.05 & 34.94 & 3.93 & 15.47 & 0.83 & 0.90 & 11.26 \\
\hline Sand & 58.91 & 81.20 & 71.36 & 9.37 & 87.86 & -0.56 & -1.82 & 13.14 \\
\hline Silt & 10.00 & 21.00 & 13.91 & 4.77 & 22.77 & 0.79 & -1.49 & 34.31 \\
\hline Clay & 8.80 & 21.39 & 14.73 & 4.79 & 22.91 & 0.25 & -1.68 & 32.49 \\
\hline Silt+Clay & 18.80 & 41.09 & 28.64 & 9.37 & 87.86 & 0.56 & -1.82 & 32.73 \\
\hline CEC & 7.37 & 17.81 & 14.16 & 3.50 & 12.25 & -1.28 & 2.03 & 24.73 \\
\hline $\mathrm{OC}$ & 0.21 & 0.38 & 0.30 & 0.06 & 0.00 & -0.19 & -0.13 & 18.86 \\
\hline $\mathrm{CaCO}_{3}$ & 0.18 & 1.54 & 0.64 & 0.50 & 0.25 & 1.10 & -0.56 & 77.54 \\
\hline Available N & 84.51 & 202.20 & 129.13 & 35.81 & 1282.00 & 1.51 & 3.84 & 27.73 \\
\hline Available P & 8.37 & 18.47 & 11.60 & 3.45 & 11.87 & 1.53 & 2.54 & 29.70 \\
\hline Available K & 141.21 & 269.98 & 214.93 & 43.16 & 1863.00 & -0.60 & 0.11 & 20.08 \\
\hline ESP & 3.61 & 12.59 & 8.93 & 3.36 & 11.31 & -0.34 & -1.05 & 37.68 \\
\hline $\mathrm{ECe}$ & 1.41 & 2.61 & 2.15 & 0.84 & 0.70 & -0.27 & -1.21 & 32.86 \\
\hline $\mathrm{pH}$ & 7.18 & 8.42 & 7.56 & 0.45 & 0.20 & 2.02 & 4.62 & 5.95 \\
\hline SARe & 3.04 & 8.01 & 5.18 & 2.44 & 5.97 & 1.09 & -0.79 & 47.19 \\
\hline \multicolumn{9}{|c|}{ Soluble cations in saturation extract $\left(\mathrm{meq} \mathrm{l}^{-1}\right)$} \\
\hline $\mathrm{Ca}^{2+}$ & 4.25 & 9.94 & 7.00 & 2.28 & 5.20 & 0.29 & -1.49 & 32.58 \\
\hline $\mathrm{Mg}^{2+}$ & 2.54 & 9.56 & 4.54 & 2.39 & 5.71 & 1.96 & 4.00 & 52.62 \\
\hline $\mathrm{Na}^{+}$ & 6.17 & 21.21 & 12.13 & 5.59 & 31.19 & 0.98 & -0.54 & 46.03 \\
\hline $\mathrm{K}^{+}$ & 0.49 & 2.24 & 1.18 & 0.62 & 0.39 & 1.00 & -0.06 & 52.86 \\
\hline \multicolumn{9}{|c|}{ Soluble anions in saturation extract $\left(\mathrm{meq}^{-1}\right)$} \\
\hline \begin{tabular}{|c|}
$\mathrm{CO}_{3}{ }^{2-}$ \\
\end{tabular} & 0.00 & 2.78 & 1.22 & 1.02 & 1.05 & 0.14 & -0.88 & 83.81 \\
\hline $\mathrm{HCO}_{3}^{-}$ & 2.74 & 14.36 & 7.63 & 4.20 & 17.66 & 0.65 & -0.76 & 55.10 \\
\hline $\mathrm{Cl}^{-}$ & 5.72 & 21.70 & 11.47 & 5.23 & 27.32 & 1.39 & 2.26 & 45.55 \\
\hline $\mathrm{SO}_{4}{ }^{2-}$ & 0.92 & 13.67 & 4.47 & 4.36 & 19.05 & 1.92 & 4.21 & 97.55 \\
\hline \multicolumn{9}{|c|}{$45-60 \mathrm{~cm}$ depth } \\
\hline SP & 31.26 & 41.42 & 34.95 & 3.87 & 14.96 & 0.87 & -0.50 & 11.07 \\
\hline Sand & 57.86 & 79.40 & 70.30 & 9.78 & 95.58 & -0.40 & -2.57 & 13.91 \\
\hline Silt & 9.60 & 21.20 & 14.42 & 5.29 & 28.01 & 0.40 & -2.48 & 36.70 \\
\hline Clay & 10.80 & 21.99 & 15.28 & 4.68 & 21.90 & 0.43 & -2.00 & 30.62 \\
\hline Silt+Clay & 20.60 & 42.14 & 29.70 & 9.78 & 95.58 & 0.40 & -2.57 & 32.91 \\
\hline CEC & 6.81 & 18.98 & 13.45 & 3.93 & 15.42 & -0.40 & 0.46 & 29.21 \\
\hline $\mathrm{OC}$ & 0.12 & 0.33 & 0.22 & 0.08 & 0.01 & 0.17 & -0.95 & 34.81 \\
\hline $\mathrm{CaCO}_{3}$ & 0.25 & 1.75 & 0.81 & 0.57 & 0.33 & 1.09 & -0.66 & 71.03 \\
\hline Available N & 79.26 & 192.40 & 116.93 & 35.59 & 1267.00 & 1.92 & 4.65 & 30.44 \\
\hline Available P & 5.24 & 12.81 & 8.79 & 2.41 & 5.79 & 0.26 & 0.69 & 27.37 \\
\hline Available K & 107.92 & 251.90 & 182.85 & 46.18 & 2132.00 & -0.27 & 0.38 & 25.25 \\
\hline ESP & 3.42 & 12.38 & 8.76 & 3.29 & 10.84 & -0.41 & -0.78 & 37.60 \\
\hline $\mathrm{ECe}$ & 1.26 & 2.45 & 1.85 & 0.87 & 0.76 & -0.02 & -1.04 & 37.10 \\
\hline $\mathrm{pH}$ & 7.06 & 8.40 & 7.46 & 0.49 & 0.24 & 2.07 & 4.78 & 6.50 \\
\hline SARe & 2.68 & 7.31 & 4.87 & 2.31 & 5.34 & 0.95 & -1.02 & 47.41 \\
\hline \multicolumn{9}{|c|}{ Soluble cations in saturation extract $\left(\mathrm{meq} 1^{-1}\right)$} \\
\hline $\mathrm{Ca}^{2+}$ & 3.36 & 9.40 & 6.45 & 2.44 & 5.97 & 0.03 & -1.63 & 37.90 \\
\hline $\mathrm{Mg}^{2+}$ & 2.40 & 9.22 & 4.11 & 2.32 & 5.40 & 2.33 & 5.73 & 56.54 \\
\hline $\mathrm{Na}^{+}$ & 5.88 & 19.84 & 10.81 & 5.03 & 25.28 & 1.14 & 0.39 & 46.50 \\
\hline $\mathrm{K}^{+}$ & 0.38 & 2.17 & 1.09 & 0.65 & 0.42 & 0.91 & -0.41 & 59.95 \\
\hline
\end{tabular}


Int.J.Curr.Microbiol.App.Sci (2017) 6(9): 835-858

Soluble anions in saturation extract $\left(\mathrm{meq}^{-1}\right)$

\begin{tabular}{|c|c|c|c|c|c|c|c|c|}
\hline $\mathrm{CO}_{3}{ }^{2-}$ & 0.00 & 2.70 & 1.06 & 0.96 & 0.92 & 0.63 & 0.16 & 90.55 \\
\hline $\mathrm{HCO}_{3}{ }^{-}$ & 2.46 & 13.82 & 6.83 & 3.91 & 15.30 & 0.86 & 0.45 & 57.23 \\
\hline $\mathrm{Cl}^{-}$ & 5.50 & 16.16 & 10.02 & 3.47 & 12.05 & 0.71 & 0.75 & 34.66 \\
\hline $\mathrm{SO}_{4}{ }^{2-}$ & 0.79 & 12.94 & 4.02 & 4.20 & 17.64 & 2.02 & 4.44 & 104.54 \\
\hline
\end{tabular}

Table.4 Descriptive statistics of soil characteristics (0-60 $\mathrm{cm}$ depth) of salt affected soil

\begin{tabular}{|c|c|c|c|c|c|c|c|c|}
\hline Characteristics & Minimum & Maximum & Mean & Std. Deviation & Variance & Skewness & Kurtosis & $\mathrm{CV}$ \\
\hline \multicolumn{9}{|c|}{$0-15 \mathrm{~cm}$ depth } \\
\hline SP & 29.94 & 43.45 & 36.01 & 4.85 & 23.52 & 0.36 & -1.51 & 13.47 \\
\hline Sand & 59.44 & 86.64 & 72.85 & 8.08 & 65.22 & -0.39 & 0.21 & 11.09 \\
\hline Silt & 7.60 & 26.53 & 12.57 & 5.63 & 31.74 & 1.89 & 3.36 & 44.80 \\
\hline Clay & 5.76 & 23.30 & 14.57 & 5.02 & 25.18 & 0.13 & 0.06 & 34.44 \\
\hline Silt+Clay & 13.36 & 40.56 & 27.15 & 8.08 & 65.22 & 0.39 & 0.21 & 29.75 \\
\hline CEC & 3.18 & 19.60 & 12.77 & 5.22 & 27.24 & -0.42 & -0.74 & 40.88 \\
\hline $\mathrm{OC}$ & 0.28 & 0.46 & 0.35 & 0.07 & 0.00 & 0.44 & -1.30 & 18.47 \\
\hline $\mathrm{CaCO}_{3}$ & 0.10 & 1.25 & 0.39 & 0.60 & 0.36 & 2.59 & 6.75 & 154.64 \\
\hline Available N & 92.04 & 195.30 & 153.95 & 29.18 & 851.69 & -0.79 & 0.63 & 18.96 \\
\hline Available P & 10.12 & 28.05 & 20.04 & 5.05 & 25.53 & -0.42 & 0.07 & 25.22 \\
\hline Available K & 196.68 & 304.15 & 262.40 & 33.80 & 1142.00 & -0.97 & 0.14 & 12.88 \\
\hline ESP & 25.00 & 72.26 & 43.79 & 15.04 & 226.18 & 0.55 & -0.59 & 34.34 \\
\hline $\mathrm{ECe}$ & 2.75 & 15.82 & 6.07 & 3.61 & 13.01 & 2.22 & 5.94 & 59.46 \\
\hline $\mathrm{pH}$ & 8.43 & 9.74 & 9.05 & 0.46 & 0.21 & 0.44 & -1.48 & 5.11 \\
\hline \begin{tabular}{|c|} 
SARe \\
\end{tabular} & 5.71 & 36.85 & 15.18 & 9.39 & 88.09 & 1.33 & 1.86 & 61.83 \\
\hline \multicolumn{9}{|c|}{ Soluble cations in saturation extract $\left(\mathrm{meq} \mathrm{l}^{-1}\right)$} \\
\hline $\mathrm{Ca}^{2+}$ & 2.72 & 19.34 & 9.35 & 5.40 & 29.13 & 0.66 & -0.39 & 57.72 \\
\hline $\mathrm{Mg}^{2+}$ & 2.67 & 15.28 & 7.87 & 4.15 & 17.23 & 0.60 & -0.50 & 52.71 \\
\hline $\mathrm{Na}^{+}$ & 14.20 & 134.92 & 42.66 & 33.14 & 1098.00 & 2.45 & 7.07 & 77.69 \\
\hline $\mathrm{K}^{+}$ & 0.71 & 4.13 & 2.04 & 1.04 & 1.09 & 0.58 & 0.10 & 51.09 \\
\hline \multicolumn{9}{|c|}{ Soluble anions in saturation extract $\left(\mathrm{meq} 1^{-1}\right)$} \\
\hline $\mathrm{CO}_{3}{ }^{2-}$ & 0.00 & 4.80 & 2.04 & 1.52 & 2.32 & 0.33 & -0.93 & 74.59 \\
\hline $\mathrm{HCO}_{3}^{-}$ & 2.87 & 23.96 & 12.83 & 7.35 & 54.07 & -0.08 & -1.41 & 57.32 \\
\hline $\mathrm{Cl}^{-}$ & 12.42 & 88.93 & 34.07 & 22.18 & 492.08 & 1.74 & 3.29 & 65.11 \\
\hline $\mathrm{SO}_{4}{ }^{2-}$ & 0.62 & 69.12 & 12.74 & 19.02 & 361.62 & 3.11 & 10.06 & 149.31 \\
\hline \multicolumn{9}{|c|}{$15-30 \mathrm{~cm}$ depth } \\
\hline $\mathrm{SP}$ & 30.25 & 44.28 & 35.97 & 4.78 & 22.89 & 0.73 & -0.83 & 13.30 \\
\hline Sand & 58.58 & 82.34 & 72.84 & 6.70 & 44.91 & -1.04 & 0.99 & 9.20 \\
\hline Silt & 7.10 & 27.96 & 12.53 & 5.90 & 34.78 & 2.06 & 4.78 & 47.07 \\
\hline Clay & 8.18 & 23.20 & 14.63 & 3.89 & 15.16 & 0.83 & 1.78 & 26.61 \\
\hline Silt+Clay & 17.66 & 41.42 & 27.16 & 6.70 & 44.91 & 1.04 & 0.99 & 24.67 \\
\hline CEC & 7.64 & 19.04 & 12.57 & 3.34 & 11.13 & 0.10 & 0.33 & 26.54 \\
\hline $\mathrm{OC}$ & 0.21 & 0.38 & 0.28 & 0.06 & 0.00 & 0.46 & -1.23 & 20.14 \\
\hline $\mathrm{CaCO}_{3}$ & 0.15 & 1.42 & 0.49 & 0.67 & 0.45 & 2.58 & 6.75 & 135.62 \\
\hline Available N & 76.56 & 185.33 & 138.80 & 31.57 & 996.89 & -0.46 & -0.06 & 22.75 \\
\hline Available P & 9.32 & 19.18 & 14.85 & 3.42 & 11.72 & -0.48 & -0.67 & 23.05 \\
\hline Available K & 124.11 & 286.23 & 218.52 & 60.04 & 3605.00 & -0.56 & -1.41 & 27.48 \\
\hline ESP & 22.76 & 69.31 & 40.14 & 14.29 & 204.30 & 0.76 & 0.08 & 35.61 \\
\hline ECe & 1.84 & 11.43 & 5.13 & 2.72 & 7.39 & 1.24 & 1.93 & 52.93 \\
\hline $\mathrm{pH}$ & 8.36 & 9.63 & 8.91 & 0.43 & 0.19 & 0.54 & -1.38 & 4.87 \\
\hline SARe & 4.84 & 34.39 & 14.35 & 9.12 & 83.12 & 1.13 & 1.12 & 63.53 \\
\hline \multicolumn{9}{|c|}{ Soluble cations in saturation extract ( $\mathrm{meq} \mathrm{1}^{-1}$ ) } \\
\hline $\mathrm{Ca}^{2+}$ & 2.46 & 17.26 & 7.80 & 4.47 & 20.02 & 0.77 & 0.51 & 57.38 \\
\hline $\mathrm{Mg}^{2+}$ & 2.42 & 12.08 & 6.17 & 3.38 & 11.41 & 0.82 & -0.37 & 54.76 \\
\hline $\mathrm{Na}^{+}$ & 9.62 & 98.02 & 35.69 & 24.41 & 595.71 & 1.73 & 4.12 & 68.39 \\
\hline $\mathrm{K}^{+}$ & 0.55 & 3.85 & 1.60 & 0.99 & 0.99 & 1.16 & 1.48 & 62.10 \\
\hline
\end{tabular}


Int.J.Curr.Microbiol.App.Sci (2017) 6(9): 835-858

\begin{tabular}{|c|c|c|c|c|c|c|c|c|}
\hline $\mathrm{CO}_{3}{ }^{2-}$ & 0.00 & 4.86 & 1.70 & 1.51 & 2.28 & 0.87 & 0.21 & 88.80 \\
\hline $\mathrm{HCO}_{3}{ }^{-}$ & 2.96 & 22.10 & 11.38 & 6.92 & 47.95 & 0.04 & -1.51 & 60.84 \\
\hline $\mathrm{Cl}^{-}$ & 9.64 & 67.58 & 28.59 & 17.78 & 316.08 & 1.43 & 1.46 & 62.19 \\
\hline $\mathrm{SO}_{4}{ }^{2-}$ & 0.43 & 40.18 & 8.70 & 10.76 & 115.80 & 2.96 & 9.36 & 123.68 \\
\hline \multicolumn{9}{|c|}{$30-45 \mathrm{~cm}$ depth } \\
\hline SP & 30.28 & 44.21 & 36.46 & 5.46 & 29.77 & 0.21 & -1.96 & 14.96 \\
\hline Sand & 57.66 & 79.95 & 71.64 & 7.30 & 53.27 & -0.62 & -0.67 & 10.19 \\
\hline Silt & 6.10 & 20.24 & 12.19 & 4.15 & 17.24 & 0.83 & 0.06 & 34.07 \\
\hline Clay & 9.53 & 27.40 & 16.17 & 5.63 & 31.65 & 0.62 & -0.18 & 34.79 \\
\hline Silt+Clay & 20.05 & 42.34 & 28.36 & 7.30 & 53.27 & 0.62 & -0.67 & 25.74 \\
\hline CEC & 7.15 & 20.93 & 12.54 & 4.18 & 17.50 & 0.64 & 0.36 & 33.37 \\
\hline $\mathrm{OC}$ & 0.13 & 0.25 & 0.20 & 0.04 & 0.00 & -0.11 & -0.54 & 19.25 \\
\hline $\mathrm{CaCO}_{3}$ & 0.18 & 1.96 & 1.18 & 1.70 & 2.90 & 2.41 & 5.97 & 144.47 \\
\hline Available N & 64.13 & 166.75 & 121.88 & 35.44 & 1256.00 & -0.41 & -0.88 & 29.08 \\
\hline Available P & 8.02 & 13.76 & 10.98 & 2.20 & 4.84 & 0.00 & -1.77 & 20.04 \\
\hline Available K & 112.32 & 263.76 & 188.98 & 52.16 & 2721.00 & -0.10 & -1.32 & 27.60 \\
\hline ESP & 22.65 & 65.07 & 37.78 & 12.69 & 160.98 & 0.94 & 0.73 & 33.58 \\
\hline $\mathrm{ECe}$ & 1.50 & 9.69 & 4.58 & 2.28 & 5.20 & 0.97 & 1.40 & 49.82 \\
\hline $\mathrm{pH}$ & 7.84 & 9.41 & 8.74 & 0.45 & 0.21 & -0.23 & 0.13 & 5.20 \\
\hline \begin{tabular}{|c|} 
SARe \\
\end{tabular} & 3.96 & 31.29 & 13.33 & 8.15 & 66.35 & 0.97 & 1.08 & 61.10 \\
\hline \multicolumn{9}{|c|}{ Soluble cations in saturation extract $\left(\mathrm{meq}^{-1}\right)$} \\
\hline $\mathrm{Ca}^{2+}$ & 2.23 & 14.30 & 6.87 & 3.72 & 13.82 & 0.55 & -0.08 & 54.14 \\
\hline $\mathrm{Mg}^{2+}$ & 2.21 & 10.86 & 5.31 & 3.00 & 9.01 & 0.90 & -0.40 & 56.52 \\
\hline $\mathrm{Na}^{+}$ & 7.12 & 84.36 & 31.18 & 20.87 & 435.57 & 1.67 & 4.14 & 66.93 \\
\hline $\mathrm{K}^{+}$ & 0.24 & 3.78 & 1.30 & 1.03 & 1.07 & 1.49 & 2.52 & 79.81 \\
\hline \multicolumn{9}{|c|}{ Soluble anions in saturation extract $\left(\mathrm{meq} \mathrm{l}^{-1}\right)$} \\
\hline $\mathrm{CO}_{3}{ }^{2-}$ & 0.00 & 4.74 & 1.29 & 1.45 & 2.11 & 1.64 & 2.34 & 112.81 \\
\hline $\mathrm{HCO}_{3}{ }^{-}$ & 2.44 & 21.68 & 10.42 & 6.92 & 47.82 & 0.14 & -1.43 & 66.34 \\
\hline $\mathrm{Cl}^{-}$ & 8.30 & 61.04 & 24.67 & 15.77 & 248.72 & 1.43 & 1.87 & 63.92 \\
\hline $\mathrm{SO}_{4}{ }^{2-}$ & 0.32 & 33.85 & 7.17 & 9.12 & 83.20 & 2.96 & 9.34 & 127.20 \\
\hline \multicolumn{9}{|c|}{$45-60 \mathrm{~cm}$ depth } \\
\hline $\mathrm{SP}$ & 31.10 & 44.75 & 36.73 & 5.25 & 27.58 & 0.55 & -1.40 & 14.30 \\
\hline Sand & 54.40 & 78.48 & 70.10 & 8.06 & 64.91 & -0.99 & -0.13 & 11.49 \\
\hline Silt & 8.70 & 21.66 & 12.67 & 4.36 & 18.99 & 1.45 & 0.91 & 34.39 \\
\hline Clay & 10.36 & 26.80 & 17.23 & 5.64 & 31.86 & 0.49 & -1.26 & 32.76 \\
\hline Silt+Clay & 21.52 & 45.60 & 29.90 & 8.06 & 64.91 & 0.99 & -0.13 & 26.94 \\
\hline CEC & 6.43 & 19.75 & 12.22 & 4.67 & 21.82 & 0.28 & -1.38 & 38.22 \\
\hline $\mathrm{OC}$ & 0.06 & 0.20 & 0.12 & 0.04 & 0.00 & 0.95 & 0.42 & 36.46 \\
\hline $\mathrm{CaCO}_{3}$ & 0.28 & 2.52 & 1.73 & 2.45 & 6.00 & 2.18 & 4.81 & 141.93 \\
\hline Available N & 55.68 & 156.97 & 109.23 & 37.13 & 1378.00 & 0.03 & -1.66 & 33.99 \\
\hline Available P & 6.21 & 12.43 & 8.64 & 2.14 & 4.60 & 0.86 & -0.09 & 24.83 \\
\hline Available K & 92.15 & 251.30 & 164.97 & 48.98 & 2399.00 & 0.07 & -0.77 & 29.69 \\
\hline ESP & 21.61 & 56.79 & 33.63 & 10.66 & 113.64 & 0.93 & 0.72 & 31.70 \\
\hline $\mathrm{ECe}$ & 1.44 & 7.21 & 3.83 & 1.76 & 3.11 & 0.29 & -0.37 & 46.07 \\
\hline $\mathrm{pH}$ & 7.39 & 9.32 & 8.60 & 0.51 & 0.26 & -1.04 & 2.79 & 5.93 \\
\hline SARe & 3.94 & 21.79 & 11.24 & 5.80 & 33.61 & 0.39 & -0.54 & 51.60 \\
\hline \multicolumn{9}{|c|}{ Soluble cations in saturation extract $\left(\mathrm{meq}^{-1}\right)$} \\
\hline $\mathrm{Ca}^{2+}$ & 1.64 & 9.34 & 5.60 & 2.76 & 7.61 & -0.11 & -1.64 & 49.28 \\
\hline $\mathrm{Mg}^{2+}$ & 1.42 & 8.62 & 4.60 & 2.45 & 6.01 & 0.48 & -1.09 & 53.29 \\
\hline $\mathrm{Na}^{+}$ & 7.04 & 56.88 & 24.40 & 14.54 & 211.41 & 0.99 & 1.20 & 59.59 \\
\hline $\mathrm{K}^{+}$ & 0.18 & 3.40 & 1.01 & 0.92 & 0.85 & 1.90 & 4.50 & 90.89 \\
\hline \multicolumn{9}{|c|}{ Soluble anions in saturation extract $\left(\mathrm{meq} \mathrm{1}^{-1}\right)$} \\
\hline $\mathrm{CO}_{3}{ }^{2-}$ & 0.00 & 4.58 & 1.09 & 1.44 & 2.06 & 1.82 & 2.88 & 131.54 \\
\hline $\mathrm{HCO}_{3}{ }^{-}$ & 2.32 & 19.52 & 9.06 & 6.36 & 40.48 & 0.46 & -1.37 & 70.23 \\
\hline $\mathrm{Cl}^{-}$ & 6.64 & 55.00 & 20.89 & 14.00 & 195.98 & 1.53 & 2.86 & 67.03 \\
\hline $\mathrm{SO}_{4}{ }^{2-}$ & 0.24 & 20.21 & 5.10 & 5.41 & 29.31 & 2.49 & 7.15 & 106.09 \\
\hline
\end{tabular}


Table.5 Estimation of the salt affected area of block Gohana, Sonipat

\begin{tabular}{|l|l|}
\hline Area and Soil Type & Area in Hectares \\
\hline Total area of the block & 36448 \\
\hline Total salt affected area & $880(2.41)^{*}$ \\
\hline Moderately salt affected & $412(1.13)^{*}$ \\
\hline Strongly salt affected & $468(1.28)^{*}$ \\
\hline
\end{tabular}

*Bracket values indicate percentage

Table.6 Keys for identification of salt affected area

\begin{tabular}{|c|c|c|c|}
\hline Class & $\mathrm{EC}_{\mathrm{e}}\left(\mathrm{dSm}^{-1}\right)$ & $\mathrm{pH}$ & ESP \\
\hline Saline & $>4$ & $<8.5$ & $<15$ \\
\hline Saline-sodic & $>4$ & 8.5 & $>15$ \\
\hline Sodic & $<4$ & $>8.5$ & $>15$ \\
\hline Normal & $<4$ & $<8.5$ & $<15$ \\
\hline
\end{tabular}

Fig.1 False colour composite image of block Gohana on 1:50,000 scale

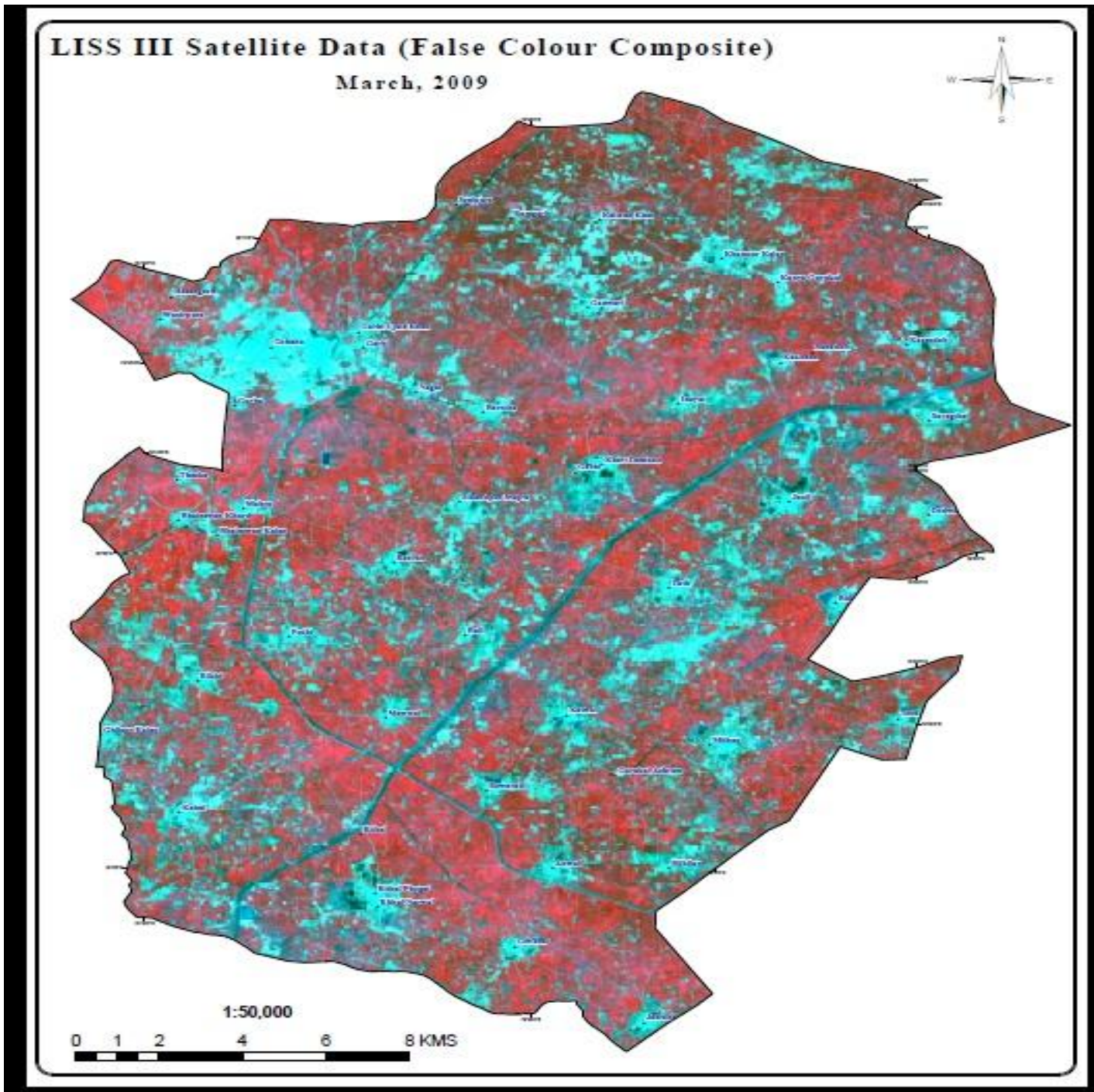


Fig.2 Spatial variability of soil $\mathrm{pH}$ at depth of $0-60 \mathrm{~cm}$

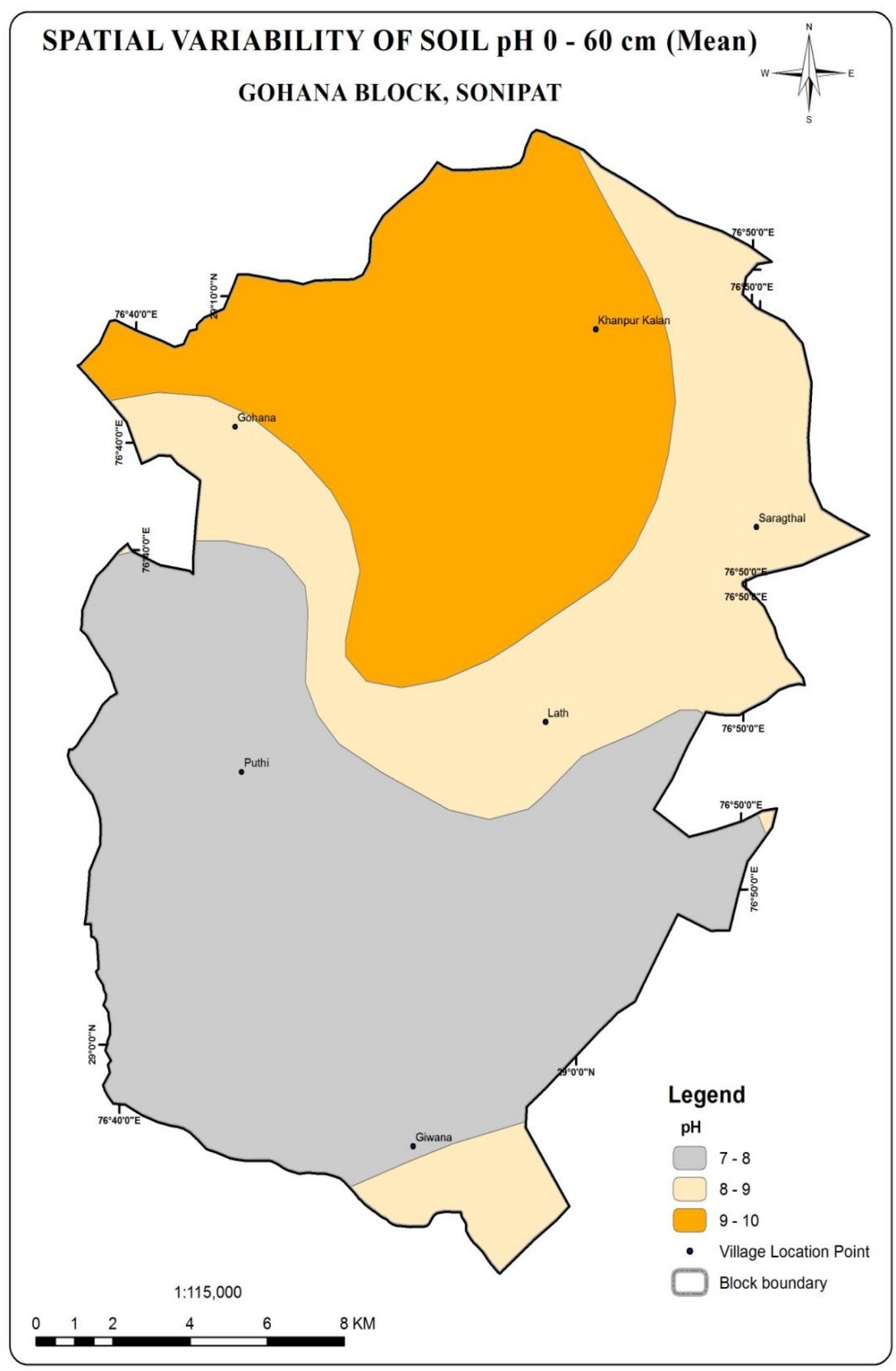


Fig.3 Spatial variability of soil $\mathrm{EC}_{\mathrm{e}}$ at depth $0-60 \mathrm{~cm}$ of block Gohana

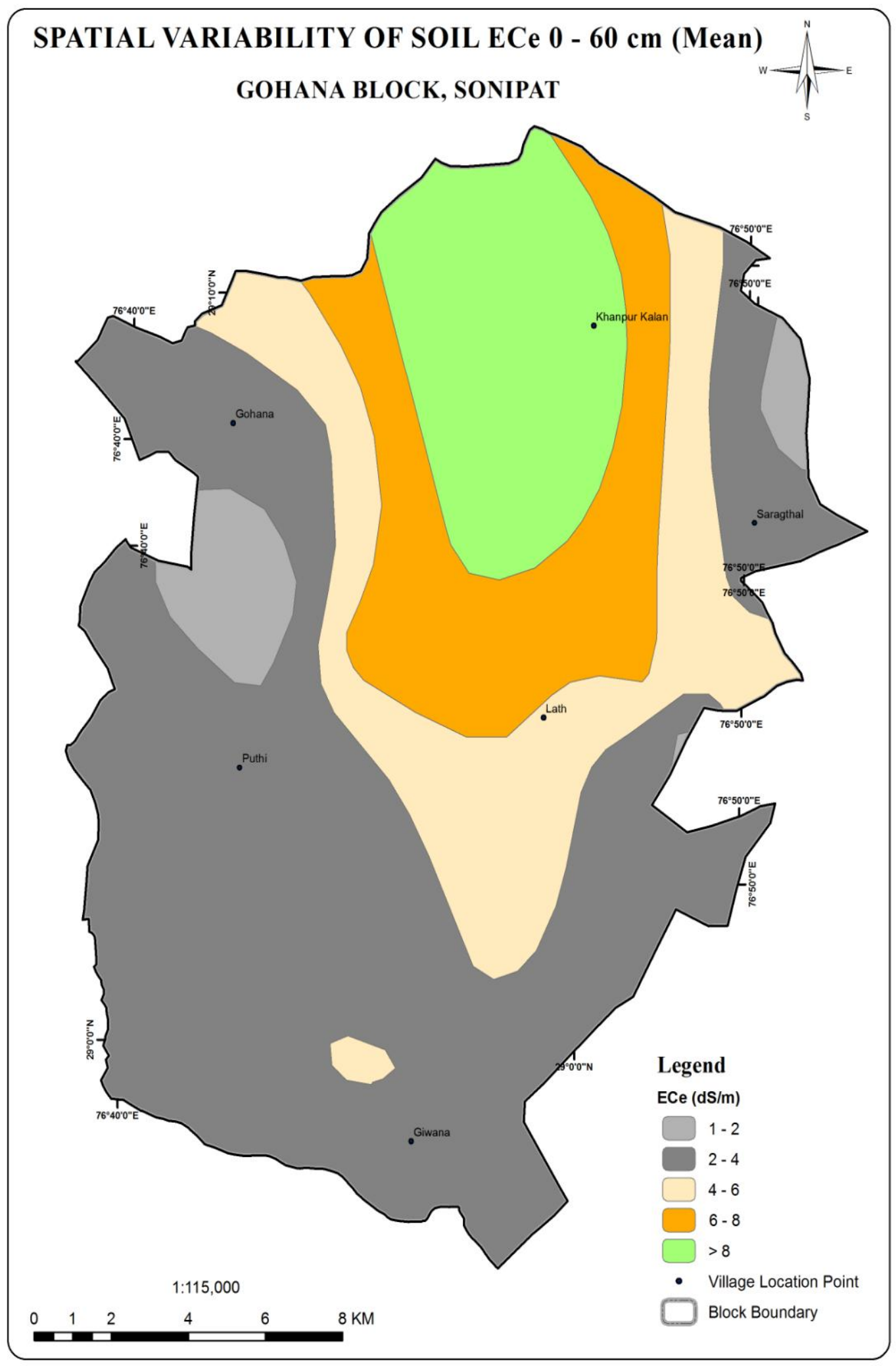


Fig.4 Spatial variability of soil ESP at depth 0-60 cm of block Gohana

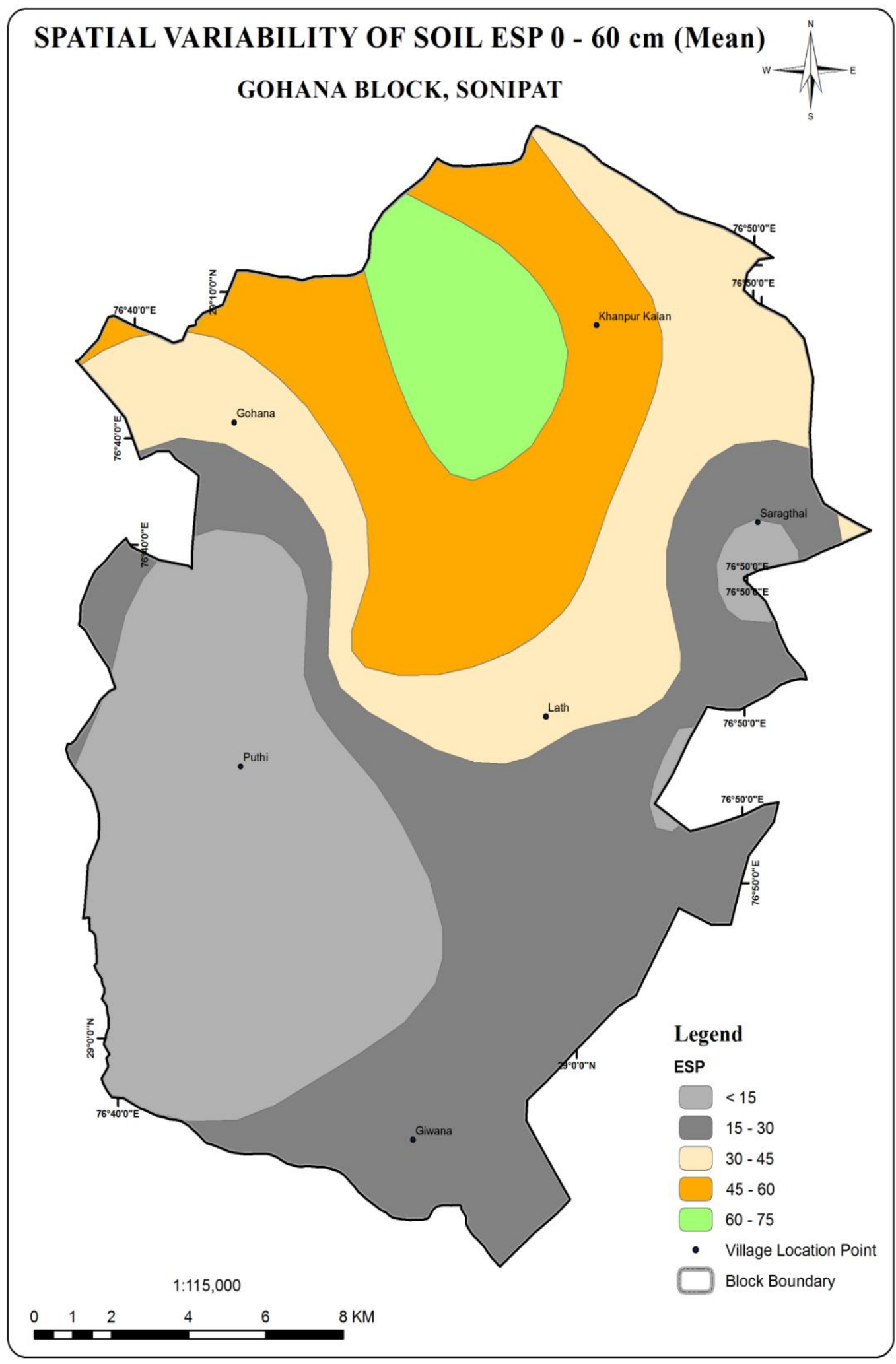


Fig.5 Soil quality map of block Gohana

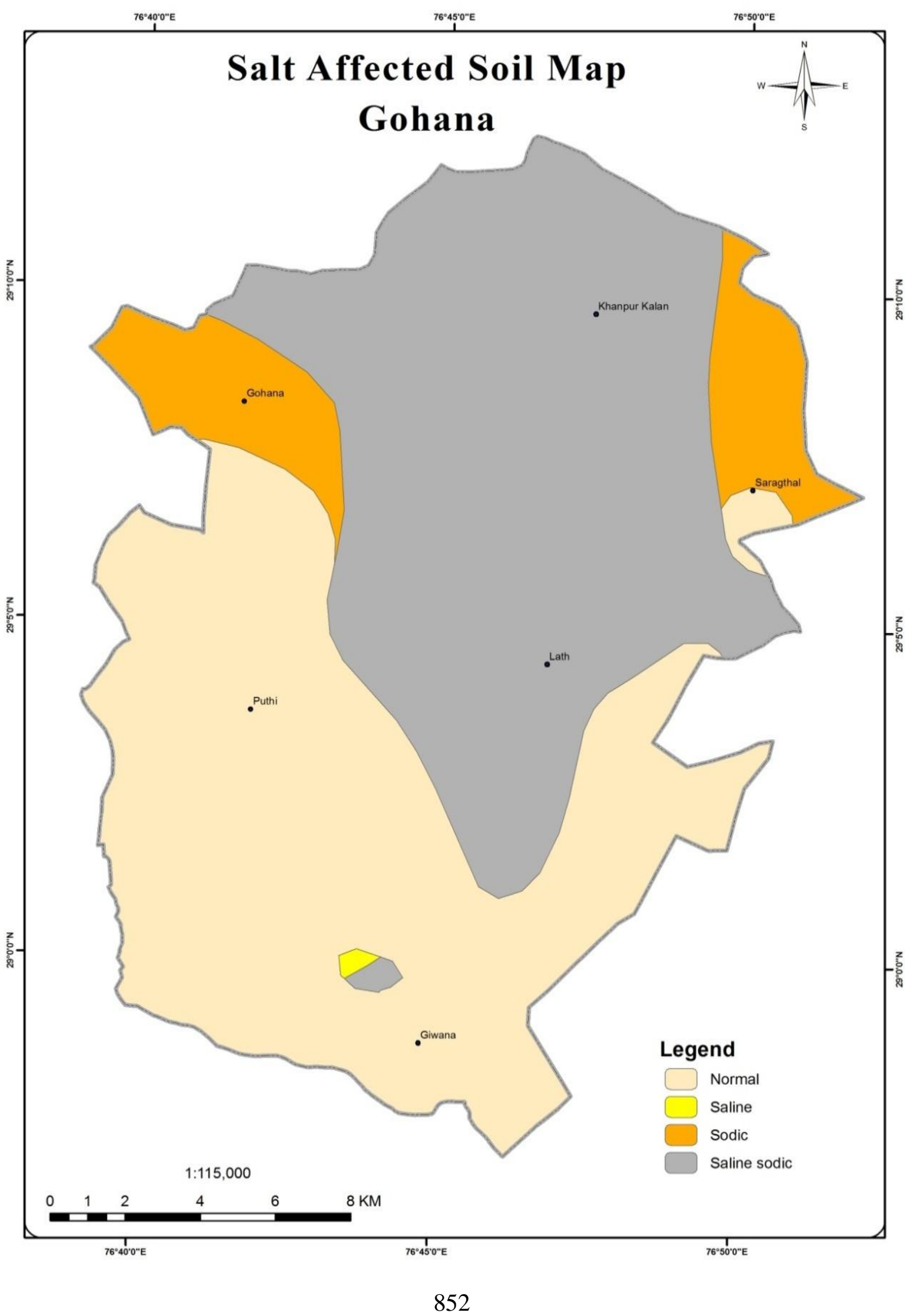


Due to low organic matter in the soil, the nitrogen is likely to be low because mineralization of organic matter is known to significantly contribute to the concentrations of nitrogen. Nitrogen showed medium variation in normal soils and low to medium in salt affected soils as indicated by $\mathrm{CV}$ values. Tripathi et al., (2015) have reported medium range of variation in available $\mathrm{N}$ with $\mathrm{CV}$ value of $37.24 \%$. There is a significant correlation of $0.56(p \leq 0.05)$ between $\mathrm{OC}$ and $\mathrm{N}$ suggesting that organic matter has influence on availability of N. As organic carbon and nitrogen exhibited significantly positive correlation (Table 2) the reduction in nitrogen with depth might be due to corresponding decrease in organic carbon with soil depth. Hailu et al., (2015) also reported strong relationship between $\mathrm{OM}$ and total $\mathrm{N}(\mathrm{r}=0.85 ; \mathrm{p}<0.01)$.

\section{Available phosphorus}

The available phosphorus ranged from 5.24 to 28.77 and 6.21 to $28.05 \mathrm{~kg} \mathrm{ha}^{-1}$ in normal and salt affected soils, respectively (Tables 3 and 4). Phosphorus showed a decreasing trend with depth which might be due to the confinement of crop cultivation to this layer and supplementation of the depleted phosphorus through external sources i.e. fertilizers. However, the reduction in available phosphorus at lower depths may be ascribed to decrease in organic carbon from surface to subsurface soil. A significant positive correlation was observed between phosphorus and organic carbon $(\mathrm{r}=0.66$; $\mathrm{p} \leq 0.01$ ) suggesting that higher available $P$ is associated with higher organic matter. Havlin et al., (2005) reported that organic matter increases $\mathrm{P}$ by anion replacement of $\mathrm{H}_{2} \mathrm{PO}_{4}{ }^{-}$ ion on adsorption sites and increasing the quantity of organic $\mathrm{P}$ mineralized to inorganic P. Phosphorus showed moderate variation in both normal and salt affected soils as indicated by CV values. Tripathi et al., (2015) have reported medium range of variation in available $\mathrm{P}$ with $\mathrm{CV}$ value of $25.95 \%$.

\section{Available potassium (K)}

The available potassium ranged from 107.92 to 323.32 and 92.15 to $304.15 \mathrm{~kg} \mathrm{ha}^{-1}$ in normal and salt affected soils, respectively. Potassium at all locations was medium in range and showed a decreasing trend with depth. The reason can be attributed to predominance of $\mathrm{K}$ rich micaceous and feldspar minerals in parent materials. One more reason can be ascribed to potassium fertilization to the surface layer. The correlation analysis shows that $\mathrm{K}$ had positive and significant correlation with organic carbon $(\mathrm{r}=0.65 ; \mathrm{p} \leq 0.01)$ and clay $(\mathrm{r}=0.21$; $\mathrm{p} \leq 0.05$ ) owing to presence of enough cation exchange sites and higher specific surface thereby retaining enough $\mathrm{K}$ on the exchange complex. Vadivelu et al., (2001) also reported positive significant correlation between available $\mathrm{K}$ and organic carbon and clay. Under saline and sodic soils, $\mathrm{K}$ fertilization management may need to be altered because of potassium competition with other cations especially $\mathrm{Na}^{+}$in the plant and to the effects of salinity in $\mathrm{K}$ reactions in soil (Bar-Tal et $a l ., 1991)$. The coefficient of variation varied sharply with depth indicating lateral and vertical variation. Tripathi et al., (2015) have reported medium range of variation in available $\mathrm{K}$ with $\mathrm{CV}$ value of $36.67 \%$.

\section{Saturation percentage (SP)}

Saturation percentage is useful for characterizing soil texture. Saturation percentage varied from 30.20 to 42.05 and 29.94 to 44.75 percent with the greatest range occurring at lower depths in both normal and salt affected soils depending upon the texture of the soil. Saturation percentage showed an irregular trend with depth which may be ascribed to the difference in texture at 
different depths. Saturation percentage showed little variation as shown by the CV values (Tables 3 and 4). Corwin and Lesch (2005) also reported low variability in SP in saline-sodic soil. A positive and significant correlation was observed between saturation percentage and clay $(\mathrm{r}=0.83 ; \mathrm{p} \leq 0.01)$ and silt $(\mathrm{r}=0.45 ; \mathrm{p} \leq 0.01)$ thereby showing the dependence of saturation percentage on finer fractions. However, the sand fraction showed highly negative and significant relationship with saturation percentage $(\mathrm{r}=-0.79 ; \mathrm{p} \leq 0.01)$. Stiven and Khan (1966) also reported positive and significant correlation between clay and saturation percentage and negative correlation between sand and saturation percentage.

\section{Soil texture}

The texture of the study area varied from loamy sand to sandy clay loam. Majority of the samples were coarse in texture. Clay content varied from 8.80 to $21.99 \%$ and 5.76 to $27.40 \%$ in normal and salt affected soils, respectively. The proportions of silt and sand varied from 9.60-21.20, 6.10-27.96 and $57.86-81.20,54.40-86.64 \%$, respectively in normal and salt affected soils (Tables 3 and 4 ). The variation in texture may be attributed to the difference in parent material and influence of pedogenesis. The coefficient of variation for sand was low as the variation in texture with depth was, by and large, small. The silt and clay proportions showed moderate variation which may be attributed to illuviation process. The mean value of silt+ clay did not show any well-defined trend with depth in normal soils, however, this parameter showed increased trend with depth in salt affected soils which may be attributed to the illuviation process. Bhatti (2002) reported low, moderate and high variability with $\mathrm{CV}$ values of 12.43, 34.12 and 55.79 for sand, silt and clay, respectively. Ameyan (1986) indicated that silt and clay had medium to high variation with CV values $18-88$.

\section{Image interpretation}

The area of salt affected soils in block Gohana is presented in table 5. Taking advantage of good contrast of surface salt encrustation and soil bareness, the satellite image was visually interpreted. Figure 1 shows the false colour composite (FCC) generated by band combination of 2, 3 and 4 in blue, green and red filters. Based on visual interpretation, the FCC demonstrates white patches followed by light bluish tone of different dimensions indicating salt efflorescence of salt-affected soils. According to spectral signatures, salt affected soils were classified into two groups, moderately salt affected and strongly salt affected. Out of $2.41 \%$ salt affected area of the block, $1.13 \%$ was moderately and $1.28 \%$ strongly salt affected. It revealed that salt-affected areas are clearly delineated. Normal and saltaffected soils exhibit differences in ground surface conditions. Salt-affected soils are characterised by the presence of various accumulated salts in the soil profile. This distinctive feature can be identified using satellite data. It is noteworthy that spectral response of salt-affected soils is higher than those of normal soils. The area under salt affected soils is mainly confined to north and northwest region of the block. The reason may be ascribed to presence of natural depression in that region which is poorly drained topographically, as a result of which water accumulates in that region and in summer due to high evapotranspiration as mercury touches almost $45^{\circ} \mathrm{C}$, the salt concentration increases which is responsible for development of salt affected soils in that region. This suggests, in agreement with Shrama (2002), that geoinformatics can be used as tool for estimating and delineation of salt affected soils. Guler et al., (2014) reported that those areas had no salinity which were higher in elevation than the areas having lower elevation, and this resulted in high 
groundwater levels that caused more severe soil salinity in low areas.

\section{Soil pH maps}

The maps of alkalinity for $0-15,15-30,30-45$ and 45-60 cm were overlayered and combined to construct a single map depicting the spatial distribution of soil $\mathrm{pH}$ over the soil depth i.e. $0-60 \mathrm{~cm}$ as shown in figure 2 . The $\mathrm{pH}$ values were divided into three classes 7-8, 8-9 and 910. Maximum area was falling under the $\mathrm{pH}$ range of $7-8$.

\section{Soil ESP maps}

The maps of sodicity (ESP) for $0-15,15-30$, $30-45$ and $45-60 \mathrm{~cm}$ were overlayered and combined to construct a single map depicting the spatial distribution of ESP for the soil depth i.e. $0-60 \mathrm{~cm}$ as shown in figure 3. The ESP values were divided into five classes i.e. $<15,15-30,30-45,45-60$ and 60-75 percent. Maximum area was falling under ESP value of $15-30$.

\section{Soil $\mathrm{EC}_{\mathrm{e}}$ maps}

The maps of electrical conductivity $\left(\mathrm{EC}_{\mathbf{e}}\right)$ for $0-15,15-30,30-45$ and 45-60 cm were overlayered and combined to construct a single map depicting the spatial distribution of $\mathrm{EC}_{\mathrm{e}}$ for the soil depth i.e. 0-60 $\mathrm{cm}$ as shown in figure 4 . The $\mathrm{EC}_{\mathbf{e}}$ values were divided into five classes i.e. 1-2, 2-4, 4-6, 6-8 and $>8 \mathrm{dSm}^{-1}$. Maximum area was falling under $\mathrm{EC}_{\mathbf{e}}$ value of 2-4 $\mathrm{dSm}^{-1}$.

\section{Soil quality map}

The soil quality map of block Gohana was constructed to illustrate the spatial distribution of salt affected areas and is represented in figure 5. Since, the soil quality is a function of $\mathrm{EC}_{\mathrm{e}}, \mathrm{pH}$ and $\mathrm{ESP}$; the soil quality maps were prepared by combining the $\mathrm{EC}_{\mathrm{e}}, \mathrm{pH}$ and $\mathrm{ESP}$ maps in a mathematical manipulation to assess various levels of salinity and sodicity of block Gohana. By combining and overlapping the thematic maps of study area, the soil quality map was prepared. The classification algorithm for salt affected soils was developed as per the guidelines of US Salinity Laboratory which is given in table 6 . Finally the classification algorithm was run to produce the final soil quality map of saline, saline-sodic, sodic and normal areas. Figure 5 demonstrate the soil quality map of the study area. These three maps based on EC, $\mathrm{pH}$ and ESP were then overlapped and combined to classify the entire area of the block. All soil quality classes, i.e. saline, saline-sodic, sodic and normal were identified in the study area. Most of the study area was having salinesodic soil.

From the results of the study, it is concluded that the physicochemical characteristics of salt affected soils of Gohana block showed complex saline and sodic nature. Within the analysis of soil samples, a large amount of variation occurred signifying that the sources and factors influencing soil properties were complex. The use of poor quality waters resulted in salt accumulation in the soil. At most of the sites, highest $\mathrm{EC}_{\mathrm{e}}$ and $\mathrm{SAR}_{\mathrm{e}}$ were observed in surface layer $(0-15 \mathrm{~cm})$ which gradually decreased with soil depth. However, in some sites maximum $\mathrm{SAR}_{\mathrm{e}}$ was found in lower layers depending upon the texture of soil, quality of irrigation water, management practices and rainfall pattern of particular locality. The application of geoinformatics provides a promising solution in classifying and delineating soils and is cost-effective, time-effective technology which plays pivotal role in study and management of earth resources.

\section{Acknowledgements}

The authors are grateful to Dr. V. S. Arya, HARSAC for providing necessary facilities for satellite imagery and map preparation. 


\section{References}

Abbas, A., Khan, S., Hussain, N., Hanjra, M.A., Akbar, S., 2013. Characterizing soil salinity in irrigated agriculture using a remote sensing approach. Physics and Chemistry of the Earth, 43-52.

Ameyan, O. 1986. Surface soil variability of a map unit on Niger River alluvium. Soil Science Society of America Journal, 50:1289-1293.

Babar, M. and Kaplay, R. D. 2004. Influence of canal irrigation on groundwater fluctuation and soil properties in Jayakwadi command of Maharashtra. Agropedology, 14(2): 82-86.

Bai, L., Wang, C., Zang, S., Zhang, Y., Hao, Q. And $\mathrm{Wu}, \mathrm{Y}$. 2016. Remote Sensing of Soil Alkalinity and Salinity in the Wuyu'er-Shuangyang River Basin, Northeast China. Remote Sensing, 8(163):1-16.

Bar-Tal, A., Feigenbaum, S. and Sparks, D. L. 1991. Potassium-salinity interactions in irrigated corn. Irrigation Science, 12:2735.

Bastiaanssen, W.G.M., Molden, D.J., Makin, I.W. 2000. Remote sensing for irrigated agriculture: examples from research and possible applications. Agricultural Water Management, 46, 137-155.

Bhat, M. A., Sheoran, H. S., Dar, E. A., Dahiya, H. S., Wani, S. A., Singh, I. and Singh, S. 2015. Geoinformatics as a Tool for Appraisal of Salt-Affected Soils-A Review. International Journal of Innovative Science, Engineering \& Technology, 2(10):480-490.

Bhatti, A. 2002. Geostatistical techniques and applications for managing degraded soil for sustainable production. Science Vision, 8(1):27-35.

Bilgili, A. V. 2013. Spatial assessment of soil salinity in the Harran Plain using multiple kriging techniques. Environmental Monitoring and Assessment, 185:777795.

Central Ground Water Board. 2008. Ministry of
Water Resources, Government of India, North Western Region, Chandigarh.

Corwin, D. L. and Lesch, S. M. 2005. Characterizing soil spatial variability with apparent soil electrical conductivity Part II. Case study. Computers and Electronics in Agriculture, 46:135-152.

Das, M. and Singh, R. 2006. Ion distribution in three salt affected soils as influenced by leaching. Indian Journal of Soil Conservation, 34(1): 33-36.

Deshmukh, K. K. 2012. Studies on chemical characteristics and classification of soils from Sangamner area, Ahmednagar district, Maharashtra, India. Rayasan Journal of Chemistry, 5(1): 74-85.

Dinesh, Bhat, M. A., Grewal, K. S., Sheoran, H. S. 2017. Mineralogy of soils of major geomorphic units of north-eastern Haryana, India. Journal of Applied and Natural Science, 9 (2): 924-934.

Eldardiry, E. I., El-Hady, M. A. and Zaghloul, A. M. 2013. Relationship between soil physical and chemical properties and hydrophysical soil properties under reuse of agricultural drainage water. AmericanEurasian Journal of Agricultural \& Environmental Science, 13(1): 01-06.

Eldiery, A., Garcia, L.A., Reich, R.M. 2005. Estimating soil salinity from remote sensing data in corn fields. Hydrology Days, 31-42.

FAO. 1988. Salt-affected soils and their management. FAO, Soils Bulletin, 39. Rome: Food and Agriculture Organization of the United Nations.

Farifteh, J., Van der Meer, F., Atzberger, C. and Carranza, E.J.M. 2007. Quantitative analysis of salt-affected soil reflectance spectra: A comparison of two adaptive methods (PLSR and ANN). Remote Sensing of Environment, 110: 59-78.

Ghassemi, F., Jackeman, A. J. and Nix, H. A. 1995. Salinization of land and water resources: human causes, extent, management and case studies. Wallingford: CAB International.

Güler, M., Arslan, H., Cemek, B. and Ersahin, S. 2014. Long-term changes in spatial 
variation of soil electrical conductivity and exchangeable sodium percentage in irrigated mesic ustifluvents. Agricultural Water Management, 135: 1-8.

Hailu, A. H., Kibret, K. and Gebrekidan, H. 2015. Characterization and classification of soils of Kabe Subwatershed in South Wollo Zone, Northeastern Ethiopia. African Journal of Soil Science 3(7): 134146.

Havlin, J. L., Beatson, J. D., Tisdale, S. L. and Nelson, W. L. 2005. Soil Fertility and Fertilizers - an Introduction to Nutrient Management, (7th Ed.) Pearson Education, Inc., Pearson Prentice Hall.

Hesse, P. R. 1971. A Textbook of Soil Chemical Analysis. John Murray, London, pp. 520.

Ildefonso, P. S., 2014. Advances in the prognosis of soil sodicity under dryland and irrigated conditions. International Soil and Water Conservation Research, 2(4): 50-63.

Jackson, M.L. 1973. Soil Chemical Analysis. Prentice Hall of India Pvt. Ltd., New Delhi.

Krauskopf, K. B. 1967. Introduction to Geochemistry, I ${ }^{\text {st }}$ edition. McGraw Hill, International Series, New York. pp. 1721.

Mandal, A. K. 2014. Characterization of some salt affected soils of Punjab for reclamation and management. Journal of the Indian Society of Soil Science, 62(2):161-167.

Mandal, A. K. and Sharma, R. C. 2010. Computerized Database of Salt-affected Soils in Peninsular India using Geographic Information System. Journal of the Indian Society of Soil Science, 58(1):105-116.

McBratney, A. B., Santos, M. L. M., Minasny, B. 2003. On digital soil mapping. Geoderma, 117:3-52.

Metternicht, G. I. 1996. Detecting and Monitoring Land Degradation Features and Processes in the Cochabamba Valleys, Bolivia a Synergistic Approach. University of Ghent, Belgium.
Mitran, T., Ravisankar, T., Fyzee, M.A., Suresh, J. R., Sujatha, G. and Sreenivas, K. 2015. Retrieval of soil physicochemical properties towards assessing saltaffected soils using Hyperspectral Data. Geocarto International, 30(6): 701-721.

Mohamed, D. M., Ibrahim, S. I. and Elamin, E. A. 2008. Variability and Correlation between Exchangeable Sodium Percentage and Sodium Adsorption Ratio in Vertisols of Sudan, Communications in Soil Science and Plant Analysis, 39: 2827-2838.

Muller, S. J. and Niekerk, A. V. 2016. An evaluation of supervised classifiers for indirectly detecting salt-affected areas at irrigation scheme level. International Journal of Applied Earth Observation and Geoinformation. 49:138-150.

Olsen, S. R., Cole, C. V., Watnabe, F.S. and Dean, L. A. 1954. Estimation of Available Phosphorus in Soils by Extraction with Sodium Bicarbonate. U.S. Department of Agriculture, Circular 939.

Piper, C. S. 1966. Soil and Plant Analysis. Hans Publishers, Bombay.

Qureshi, F. M., Singh, A. K., Chaudhari, S. K. and Das, K. 1996. Genesis and taxonomy of some saline and sodic soils Bharatpur (Rajasthan). Journal of the Indian Society of Soil Science, 44:130-135.

Richards, L. A. 1954. Diagnosis and improvement of saline and alkali soils. Handbook No. 60. Washington: United States Department of Agriculture.

Saldana, A., Stein, A. and Zinck, J. A. 1998. Spatial variability of soil properties at different scales within three terraces of the Henares River (Spain). Catena 33:139-153.

Salehi, M. H., Eghbal, M. K. and Khademi, H. 2003. Comparison of soil variability in a detailed and reconnaissance soil map in central Iran. Geoderma, 111:45-56.

Scott, A. D. and Smith, S. J. 1987. Sources, amounts and forms of alkali elements in soils. Advances in Soil Science, 6:101138. 
Sharma, B. D., Mukhopadhyay, S. S. and Jassal, H. S. 2011. Morphological, chemical and mineralogical characterization of developing soils and their management in western Shiwalik Himalayas. Archives of Agronomy and Soil Science, 57(6): 609630.

Sharma, R. C. 2002. Mapping and characterization of saline soils in Gohana Haryana for subsurface drainage. Agropedology, 12:104-111.

Sharma, S. K. and Gupta, I. C. 1986. Saline environment and plant growth, Agro Botanical Publication Bikaner, 172.

Sidhu, P. S., Sharma, P. K. and Bajwa, M. S. 1991. Characteristics, Distribution and Genesis of Salt-Affected Soils in Punjab. Journal of the Indian Society of Remote Sensing, 19 (4):269-276.

Stiven, G. A. and Khan, M. A. 1966. Saturation percentage as a measure of soil texture in the lower Indus Basin. Journal of Soil Science, 17(2):255-263.

Subbiah, B. V. and Asija, G. L. 1956. A Rapid Procedure for the Determination of Available Nitrogen in Soils. Current Science, 25: 259-260.

Tripathi, R., Nayak, A. K., Shahid, M., Raja, R., Panda, B. B., Mohanty, S., Kumar, A., Lal, B., Priyanka Gautam, P. and Sahoo, R. N. 2015. Characterizing spatial variability of soil properties in salt affected coastal India using geostatistics and kriging. Arabian Journal of Geosciences, 8:10693-10703.
Vadivelu, S., Sen, T. K., Bhaskar, B. P., Thampi, J., Barauh, U. And Mishra, J. P. 2001. Mapping available potassium in soils of Assam. Agropedology, 12:29-37.

Walkley, A. and Black, J. A. 1934. An examination of the Degtjareff method for determining soil organic matter and a proposed modification of the chromic acid titration method. Soil Science, 37: 29-38.

Wang, Q., Li, Y. and Klassen, W. 2005. Determination of Cation Exchange Capacity on Low to Highly Calcareous Soils. Communications in Soil Science and Plant Analysis, 36: 1479-1498.

Yang, F., Zhang, G., Yin, X. and Liu, Z. 2011. Field-Scale Spatial Variation of SalineSodic Soil and its Relation with Environmental Factors in Western Songnen Plain of China. International Journal of Environmental Research and. Public Health, 8:374-387.

Zhaoyong, Z., Abuduwaili, J., Yimit, H. 2014. The occurrence, sourcesand spatial characteristics of soil salt and assessment of soil salinization risk in Yanqi basin, northwest China. PLoS ONE, 9(9): e106079.

Zinck, J. 2000. Monitoring soil salinity from remote sensing data. In: Special Interest Group on Remote Sensing for Developing Countries, Gent, Belgium, pp. 359-368.

\section{How to cite this article:}

Mohammad Amin Bhat, M.S. Grewal, Dinesh, Inderpal Singh and Grewal, K.S. 2017. Geoinformatics for Quantifying Salt Affected Soils in Gohana, Haryana Using Soil Techniques. Int.J.Curr.Microbiol.App.Sci. 6(9): 835-858.

doi: https://doi.org/10.20546/ijcmas.2017.609.103 